OPEN ACCESS

Edited by:

Leonardo Cruz Da Rosa,

Federal University of Sergipe, Brazil

Reviewed by:

Kit Yue Kwan,

Beibu Gulf University, China

Maickel Armenteros,

National Autonomous University of

Mexico, Mexico

${ }^{*}$ Correspondence:

Ninon Mavrak

nmavraki@naturalsciences.be ninon.mavraki@gmail.com

Specialty section:

This article was submitted to

Marine Biology,

a section of the journal

Frontiers in Marine Science

Received: 26 February 2020 Accepted: 04 May 2020

Published: 04 June 2020

Citation:

Mavraki N, De Mesel I, Degraer S, Moens T and Vanaverbeke J (2020)

Resource Niches of Co-occurring Invertebrate Species at an Offshore Wind Turbine Indicate a Substantial

Degree of Trophic Plasticity.

Front. Mar. Sci. 7:379

doi: 10.3389/fmars.2020.00379

\section{Resource Niches of Co-occurring Invertebrate Species at an Offshore Wind Turbine Indicate a Substantial Degree of Trophic Plasticity}

\author{
Ninon Mavraki ${ }^{1,2 *}$, Ilse De Mesel ${ }^{1}$, Steven Degraer ${ }^{1,2}$, Tom Moens ${ }^{2}$ and \\ Jan Vanaverbeke ${ }^{1,2}$
}

${ }^{1}$ Royal Belgian Institute of Natural Sciences, Operational Directorate Natural Environment, Marine Ecology and Management, Brussels, Belgium, ${ }^{2}$ Marine Biology Research Group, Department of Biology, Ghent University, Ghent, Belgium

Offshore wind farms (OWFs) in the North Sea are proliferating, causing alterations in local ecosystems by adding artificial hard substrates into naturally soft-bottom areas. These substrates are densely colonized by fouling organisms, which may compete for the available resources. While the distribution of some species is restricted to specific parts of the turbine, others occur across depth zones and may therefore face different competitive environments. Here we investigate the trophic niches of seven invertebrate species: three sessile (Diadumene cincta, Metridium senile, and Mytilus edulis), one hemi-sessile (Jassa herdmani) and three mobile species (Ophiothrix fragilis, Necora puber, and Pisidia longicornis) that occur in multiple depth zones. We hypothesized that these species would be trophic generalists, exhibiting trophic plasticity by selecting different resources in different depth zones, to cope with the different competitive environments in which they occur. We analyzed $\delta^{13} \mathrm{C}$ and $\delta^{15} \mathrm{~N}$ of these species and their potential resources across depth zones. Our results show that most of these invertebrates are indeed trophic generalists which display substantial trophic plasticity, selecting different resources in different zones. Degree of trophic plasticity was not related to mobility of the species. There are two possible explanations for these dietary changes with depth: either consumers switch diet to avoid competition with other (dominant) species, or they benefit from the consumption of a non-limiting resource. Only Diadumene cincta was a trophic specialist that consumed suspended particulate organic matter (SPOM) independent of its zone of occurrence. Altogether, trophic plasticity appears an important mechanism for the co-existence of invertebrate species along the depth gradient of an offshore wind turbine.

Keywords: artificial habitats, feeding strategy, offshore wind farms, stable isotope analysis, trophic generalist, trophic specialist

\section{INTRODUCTION}

In many countries across the world, and in Europe in particular, offshore wind farms (OWFs) are increasingly being considered a potentially significant contributor in the quest to reduce $\mathrm{CO}_{2}$ emissions. By 2018, 4149 offshore wind turbines had been installed in European marine waters, producing a total of $15.8 \mathrm{GW}$, while this capacity is expected to increase up to $70 \mathrm{GW}$ in 2030 
(WindEurope, 2018). In the North Sea, new wind farms are continuously being constructed, licensed or scheduled (Soma et al., 2019).

The construction of offshore wind turbines creates a new benthic habitat, adding hard substrate to naturally soft-bottom areas. These hard substrates are colonized by dense hardbottom assemblages (Wilhelmsson and Malm, 2008; Krone et al., 2013; De Mesel et al., 2015), consisting mainly of filter-feeders (Lindeboom et al., 2011) and other fouling organisms (Slavik et al., 2018) that may compete for food and space (Buss and Jackson, 1981; Dubois and Colombo, 2014; Cresson et al., 2016). Filter-feeders capture suspended food particles that are highly diluted in the water column (Gili and Coma, 1998). These organisms have developed mechanisms to select specific food particles from the available spectrum (Dubois et al., 2007; Dubois and Colombo, 2014) and exploit a variety of resources that may change through space and time (Bode et al., 2006; Richoux et al., 2014). Hence, species within the same feeding guild can have different resource use strategies, limiting competition for food through trophic niche partitioning (Lefebvre et al., 2009; Richoux et al., 2014).

In the North Sea, fouling communities living on wind turbines form a clear vertical zonation pattern along the depth gradient (De Mesel et al., 2015). Despite this general zonation pattern, some species occur in multiple depth zones or along the entire depth gradient of the turbine. These include both sessile organisms, such as the blue mussel Mytilus edulis and the anemone Metridium senile, and mobile species, such as the porcelain crab Pisidia longicornis, the brittle-star Ophiothrix fragilis and the crab Necora puber (Mavraki et al., 2020). The latter are not considered fouling organisms, but their presence is highly linked to the presence of artificial hard substrates (Lindeboom et al., 2011; De Mesel et al., 2015; van der Stap et al., 2016). Pisidia longicornis and O. fragilis can feed on suspended material, such as phytoplankton and pseudofaeces (Warner, 1971; Smaldon, 1972; Sampedro et al., 1997; Allen, 1998), while N. puber also preys on a variety of fouling species, such as amphipods and mussels (Freire and Gonzalez-Gurriaran, 1995). The occurrence of these species in multiple zones does not necessarily imply that they are successfully established in these zones. Temporal dynamics influence the species distribution along the depth gradient. For example, the dominance of the amphipod Jassa herdmani decreases with increasing depth in summer and in winter, while M. edulis can only be found at lower depths during winter (Kerckhof et al., 2010).

The occurrence of certain species in more than one zone suggests that they may be competing both for the available resources and/or for space with the dominant species in those zones. In benthic communities, space has long been considered as the main limiting resource (Buss and Jackson, 1981; Côté et al., 1994; Dubois and Colombo, 2014; Svensson and Marshall, 2015). However, food limitation (henceforth referred to as food or resource limitation in this paper) by co-occurring species is also recognized as an important factor influencing community functioning (Buss and Jackson, 1981; Dubois and Colombo, 2014; Cresson et al., 2016). Resource partitioning and trophic plasticity have been proposed as strategies of co-occurring organisms to limit the effects of trophic competition (Lefebvre et al., 2009; Riera, 2009). Resource partitioning is the division of limiting resources among species as a mechanism to avoid trophic competition (Ross, 1986), while trophic plasticity is the adaptation of organisms to minimize potential competition for food by (partly) shifting their diets (MacNeil et al., 1997; Lefebvre et al., 2009). Resource partitioning often entails some form of trophic specialization, leading - in the case of the invertebrate fauna associated with wind turbines - to the utilization of a narrow range of resources by specific taxa (Van Valen, 1965; Bearhop et al., 2004). Trophic plasticity, on the other hand, is a form of trophic generalism, implying that a species is capable of feeding on a broad food spectrum, but will exploit only a (partly different) part of that spectrum depending on the competitive environment in which it occurs (here, e.g., in the different depth zones) (Hazlett, 1988; Bearhop et al., 2004; Gutt, 2006; Riera, 2009). The scenario of the existence of mainly trophic generalists on offshore wind turbines is plausible, because the species would be able to co-occur in a limited amount of space by exhibiting considerable trophic plasticity (Araújo et al., 2011; Páez-Rosas et al., 2017). In any case, the co-occurrence of multiple invertebrate species on offshore wind turbines could be partly explained by their feeding behavior.

In this study, we sampled invertebrate species that occur across different zones along the depth gradient of a gravitybased offshore wind turbine, its scour protection layer (SPL) and the surrounding soft sediments in the Belgian part of the North Sea (BPNS). We hypothesized that these species would be trophic generalists that are capable of modifying their resource exploitation in different depth zones, implying that trophic plasticity is the key mechanism allowing their wide distribution and survival in a competitive environment. We used stable isotope analysis (SIA) to investigate trophic niches and pathways (Riera, 2009). The isotopic niche of a species can be estimated using SIA and is a proxy for its trophic niche (Newsome et al., 2007; Jackson et al., 2011). We would therefore expect partly different isotopic niches across depth zones within the same consumer species. In addition, we anticipated that such a niche differentiation across depth zones would translate into overall large depth-integrated isotopic niches of these species, as they are expected to be overall trophic generalists (Layman et al., 2007).

\section{MATERIALS AND METHODS}

\section{Study Site}

Samples were collected from a gravity-based wind turbine (D6 wind turbine, coordinates: $51^{\circ} 33.04^{\prime} \mathrm{N}-02^{\circ} 55.42^{\prime} \mathrm{E}$ ) within the C-Power wind farm on the Thornton Bank (BPNS), which is a sandbank located $27 \mathrm{~km}$ off the Belgian coast (Brabant and Jacques, 2010). C-Power was the first wind farm that was constructed in the BPNS in spring 2008, when D6 and 5 other gravity-based foundations were installed (Brabant and Degraer, 2010). The tidal range in the area is $4-5 \mathrm{~m}$ during spring tide 


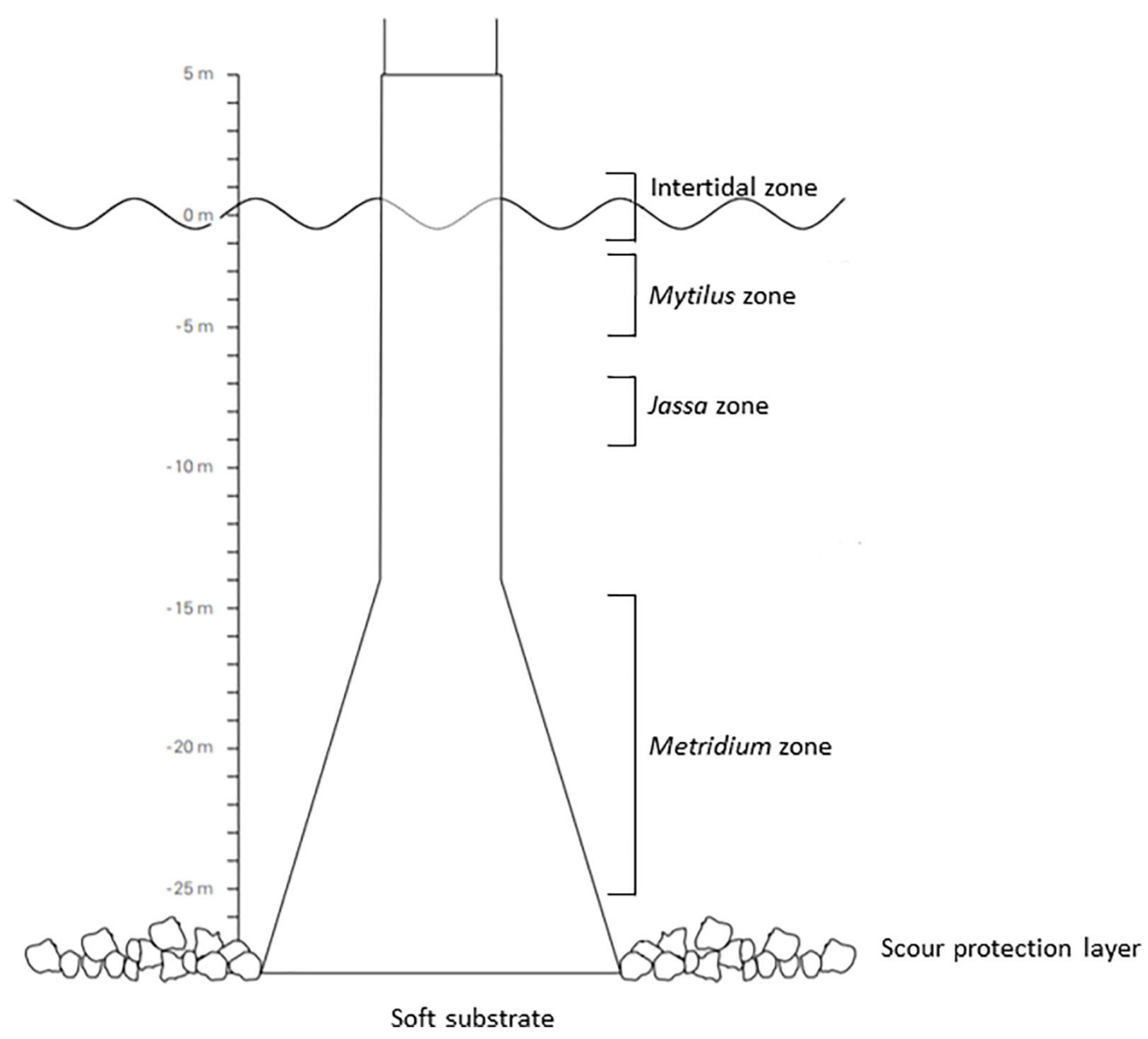

FIGURE 1 | Vertical zonation pattern based on macrofauna and structural/habitat differences along the depth gradient of an offshore wind farm gravity-based foundation (modified by the source: De Mesel et al., 2013).

(Van den Eynde et al., 2010) and the water depth varies between ca. 23 and $27 \mathrm{~m}$ (Peire et al., 2009). The currents on the Thornton Bank are directed along a north-east - south-west axis (Van den Eynde et al., 2010). The annual primary production by phytoplankton in the area is on average $213 \mathrm{~g} \mathrm{C} \mathrm{m}^{-2}$, with the spring bloom producing ca. $73 \%$ of this annual primary production (Lancelot et al., 2005). We chose this particular location because a wealth of data on fouling assemblages and soft-substrate fauna were available (Coates et al., 2014; De Mesel et al., 2015). Sampling of all the consumers and of most of their potential resources was conducted from the research vessel Simon Stevin in August 2016. Macroalgae from the intertidal were collected from an inflatable boat in August 2017.

\section{Sampling Scheme}

Invertebrate organisms living along the depth gradient on the wind turbine, the SPL and the surrounding soft sediment, as well as possible resources from the water column and the intertidal area of the turbine, were collected. Six sampling zones based on macrofaunal zonation patterns (Lindeboom et al., 2011;
Krone et al., 2013; De Mesel et al., 2015) and on structural/habitat differences (Baeye and Fettweis, 2015) were chosen for the collection of the consumer organisms: (a) the intertidal, (b) the Mytilus zone (5 $\mathrm{m}$ depth), (c) the Jassa zone ( $~ 8.5 \mathrm{~m}$ depth), (d) the Metridium zone (15-25 m depth), (e) the SPL (25-27 $\mathrm{m}$ depth) and (f) the soft sediment surrounding the turbine (soft substrate - $\sim 27 \mathrm{~m}$ depth) (Figure 1). Scientific divers collected consumer species from the Mytilus, the Jassa and the Metridium zones by scraping $(25 \times 25 \mathrm{~cm}$ frame), from the SPL by collecting rocks ( $\sim 15 \mathrm{~cm}$ length, $10 \mathrm{~cm}$ width and $5 \mathrm{~cm}$ height) and from the sediment by using an airlift suction device (surface sampled: $25 \times 25 \mathrm{~cm}$, sediment depth: $5 \mathrm{~cm}$ ). Consumers from the intertidal zone were collected by scraping from an inflatable boat at low tide. Samples were collected during the turn of the tide at neap tide. Finally, large consumers, such as large crustaceans and ophiuroids, were handpicked by scientific divers in the different subtidal zones. All consumers were identified to the lowest taxonomic level possible. Whenever possible, five individuals per species were collected from each zone for the SIA to include intraspecific variation. The individuals were 
randomly selected to more accurately quantify the width of the trophic niche of the species and ultimately understand the mechanism(s) responsible for species co-existence (Bolnick et al., 2011; Violle et al., 2012). Macrofaunal organisms were starved overnight in filtered sea-water in order to allow them to clear their gut contents. Larger crustaceans were immediately freezekilled (Zhang et al., 2018) and cheliped tissues were subsequently isolated and retained for SIA.

For the collection of candidate resources, three replicate samples (one 1-L sampling vial for each replicate) of suspended particulate organic matter (SPOM) were collected by scientific divers from the lower $(\sim 1 \mathrm{~m}$ above the sea floor - referred to as SPOM-bottom) and the upper $(\sim 3 \mathrm{~m}$ below the sea surface referred to as SPOM-surface) water column. Water samples were initially sieved through a $200 \mu \mathrm{m}$ sieve to remove large detritus and zooplankton (Lorrain et al., 2003; Banaru et al., 2014), and then filtered through pre-combusted and pre-weighed Whatman GF/F $47 \mathrm{~mm}$ filters (mesh size: $0.7 \mu \mathrm{m}$ ) using a vacuum pump. Zooplankton was collected one meter away from the turbine, using a vertical haul of the plankton net (diameter: $0.57 \mathrm{~m}$, mesh size: $200 \mu \mathrm{m}$ ). Subsequently, it was concentrated by sieving over different mesh sizes (800 and $250 \mu \mathrm{m}$ ) and separated into different size groups. The subsamples were kept in filtered sea water for 2-4 h to allow gut clearance (Smyntek et al., 2007). Macroalgae were scraped off from the intertidal both at low (algae-lower) and at high (algae-upper) tide from an inflatable boat. Since the macroalgae on the wind turbine are perennial, they are constantly available to consumers; year-round studies revealed no or only very small inter-annual variation in their isotopic signatures (Bordeyne et al., 2017). Hence, sampling macroalgae in a different year would not have an effect on their isotopic signatures. Epiphytes were scraped off the algae using a sterilized dull scalpel under a stereomicroscope prior to drying to acquire the isotopic signature of the algae (Moncreiff and Sullivan, 2001; Renaud et al., 2015). We additionally included data for sediment organic matter (SOM) that were collected during the same sampling period from the same wind farm area (Toussaint et al., unpublished data), since re-suspended SOM is a potential resource, e.g., for species inhabiting the SPL and the soft substrate.

All samples for SIA (sources and consumers) were stored in a $-20^{\circ} \mathrm{C}$ freezer until further analysis. In total, seven species were sampled in sufficient replicates from more than one depth zones: the sessile filter-feeding species Mytilus edulis, Diadumene cincta, and Metridium senile, the hemi-sessile filter-feeder Jassa herdmani, the mobile filter-feeding species Pisidia longicornis and Ophiothrix fragilis, and the mobile omnivore/predator Necora puber (Table 1).

\section{Sample Preparation}

Filters for the analysis of SPOM were thawed, dried overnight at $60^{\circ} \mathrm{C}$ and prepared for $\delta^{13} \mathrm{C}$ and $\delta^{15} \mathrm{~N}$ isotope analysis. The preparation included the bisection of the filter; one half was immediately enclosed in a tin ( $\mathrm{Sn}$ ) capsule and the other half was acidified through exposure to hydrochloric acid fumes $(\mathrm{HCl}$ $37 \%$ ) in a desiccator for the removal of the inorganic carbon (Lorrain et al., 2003). The acidified halves of the filters were dried again overnight $\left(60^{\circ} \mathrm{C}\right)$ and then enclosed in silver $(\mathrm{Ag})$ capsules. Acidification was necessary to eliminate traces of carbonates, which can significantly affect the $\delta^{13} \mathrm{C}$ values of the SPOM samples (Lorrain et al., 2003). The non-acidified samples were then analyzed for $\delta^{15} \mathrm{~N}$, which do not require pre-treatment, since acidification may contribute to some shifts in $\delta^{15} \mathrm{~N}$ (Goering et al., 1990; Vafeiadou et al., 2013).

Entire individuals of the small-sized species Jassa herdmani, Pisidia longicornis, Metridium senile, and Diadumene cincta were processed for SIA after gut content clearance. For the other organisms, specific muscle tissues were sampled: cheliped muscle from Necora puber (Reid et al., 2016), foot from Mytilus edulis (Richoux and Ndhlovu, 2015) and peristomial membrane from Ophiothrix fragilis (Andrade et al., 2016). For each species, individuals of similar size were selected to exclude effects of any size-specific shifts in diet (Cresson et al., 2016). Zooplankton subsamples were first thawed and then analyzed under a stereomicroscope for the separation of the organisms into broad taxonomic groups (Banaru et al., 2014). The largest size class $(800-1000 \mu \mathrm{m})$ contained mainly crab larvae (referred to as "Crab larvae") and other unidentified larvae (referred to as "Other larvae"). The smaller size-class (250-800 $\mu \mathrm{m})$ contained mainly copepods. The different taxonomic groups were further analyzed for SIA. Finally, macroalgae samples were also thawed and analyzed under a stereomicroscope to ensure that epiphytes had been effectively removed.

Individuals, muscle tissues, zooplankton samples and macroalgae were rinsed with milli-Q water to avoid contamination and dried overnight at $60^{\circ} \mathrm{C}$, after which they were pulverized using a mortar and pestle and homogenized. Depending on the tissue type, approximately $1 \mathrm{mg}$ of dried tissue was immediately encapsulated in a Sn capsule, weighed and stored in a desiccator until further analysis, or it was first split into two subsamples of equal dry weight (ca $1 \mathrm{mg}$ ); one subsample was used for the analysis of $\delta^{15} \mathrm{~N}$ and immediately encapsulated in a Sn capsule without prior treatment, whilst the other was transferred in a Ag capsule, acidified by adding $1 \% \mathrm{HCl}$ "drop by drop" until elimination of all $\mathrm{CO}_{2}$ from the carbonates in the sample (Jacob et al., 2005), and used for analysis of $\delta^{13} \mathrm{C}$. The latter sample was subsequently rinsed with distilled water, dried again and stored dry in multi-well Microtitre plates in a desiccator until further analysis (Pinnegar and Polunin, 1999). When the weight of the organisms was not sufficient to prepare two subsamples, more individuals of the same species and location were pooled in the same sample and formed a "compound" sample replicate. This was mainly the case for the samples that needed acidification. For all the other samples, each consumer individual was treated as a replicate. Only the organisms containing calcareous structures, i.e., Jassa herdmani, Ophiothrix fragilis, Pisidia longicornis, and zooplankton, were acidified.

In total, 206 samples (both resources and consumers Supplementary Table S1) were analyzed on a PDZ Europa ANCA-GSL elemental analyzer, interfaced to a PDZ Europa 20-20 isotope ratio mass spectrometer (Sercon Ltd., Cheshire, United Kingdom) at the UC Davis Stable Isotope Facility (University of California, United States). The results for carbon 
TABLE 1 | The seven dominant species (consumers) sampled in the different depth zones with the relative resources that were used in the mixing model per depth zone after the a posteriori combination of sources.

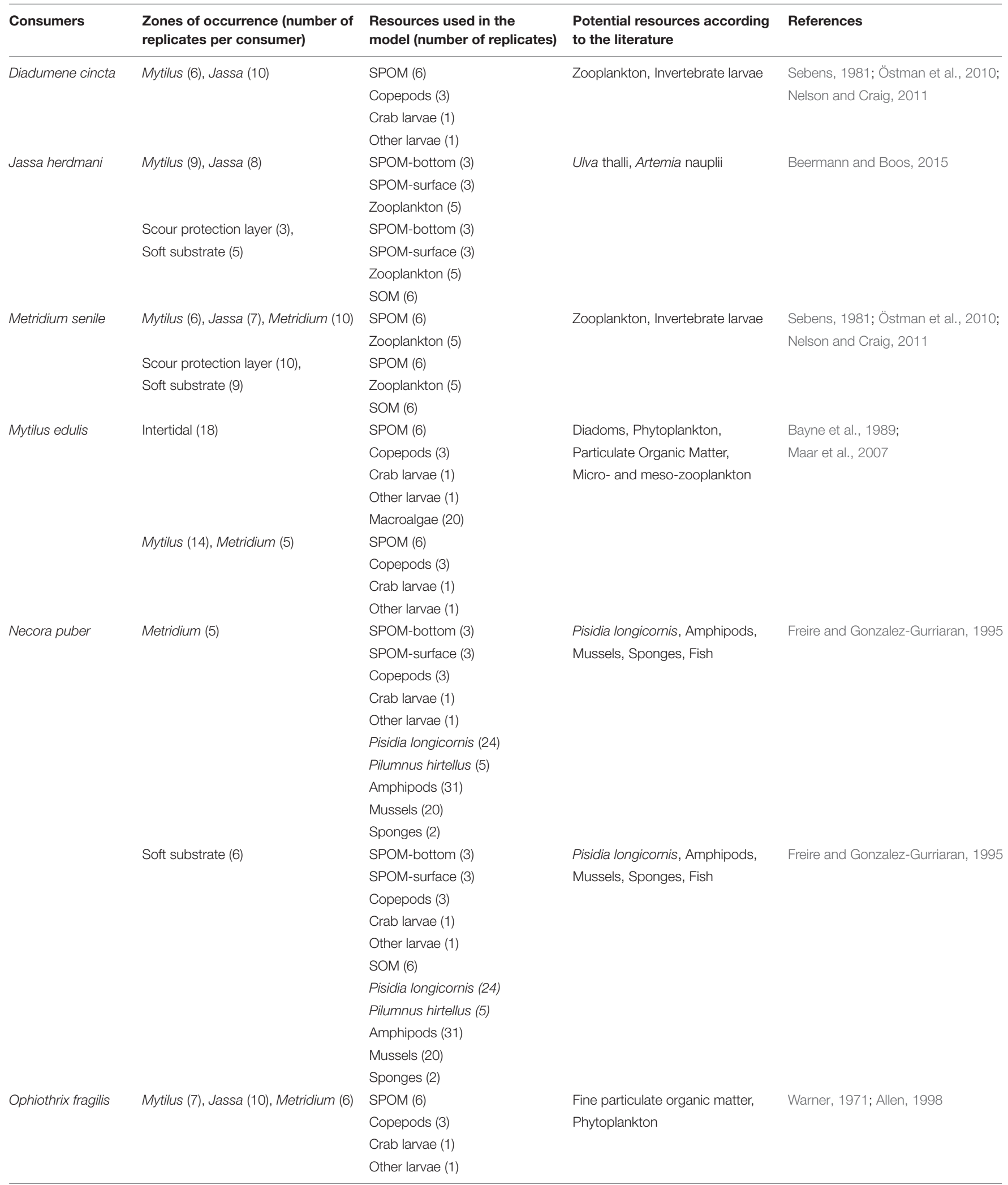


TABLE 1 | Continued

\begin{tabular}{|c|c|c|c|c|}
\hline Consumers & $\begin{array}{l}\text { Zones of occurrence (number of } \\
\text { replicates per consumer) }\end{array}$ & $\begin{array}{l}\text { Resources used in the } \\
\text { model (number of replicates) }\end{array}$ & $\begin{array}{l}\text { Potential resources according } \\
\text { to the literature }\end{array}$ & References \\
\hline \multirow[t]{9}{*}{ Pisidia longicornis } & Mytilus (8) & SPOM (6) & Pseudofaeces, suspended & Smaldon, 1972; \\
\hline & & Copepods (3) & material & Sampedro et al., 1997 \\
\hline & & Crab larvae (1) & & \\
\hline & & Other larvae (1) & & \\
\hline & Scour protection layer (13) & SPOM (6) & & \\
\hline & & Copepods (3) & & \\
\hline & & Crab larvae (1) & & \\
\hline & & Other larvae (1) & & \\
\hline & & SOM (6) & & \\
\hline
\end{tabular}

The potential resources for every species according to the literature and the respective references are found at the last two columns.

and nitrogen isotope ratios were expressed in the standard delta ( $\delta$ ) notation:

$$
\delta X=\left[\left(\frac{R_{\text {Sample }}}{R_{\text {Standard }}}\right)-1\right] \times 10^{3}
$$

where $\mathrm{X}$ is ${ }^{13} \mathrm{C}$ or ${ }^{15} \mathrm{~N}$ and $\mathrm{R}$ is the ratio of ${ }^{13} \mathrm{C} /{ }^{12} \mathrm{C}$ or ${ }^{15} \mathrm{~N} /{ }^{14} \mathrm{~N}$, expressed in $\%$. For both sources and consumers, we strived to analyze at least three replicates per species, but for some zooplankton groups this was not possible.

\section{Data Analysis}

Seven (one for every species) one-way analyses of variance (ANOVA) were conducted to examine whether the isotopic signatures differed among depth zones. Prior to the ANOVA, the assumptions of homogeneity of variances (Levene's test) and of normality of the data (Shapiro test) were examined and proved valid. Post hoc multiple comparisons were performed using the Tukey's Honest Significant Differences (HSD) test.

Furthermore, we used two different approaches to investigate the diet composition of each consumer in the different zones. For each species, we first characterized the isotopic niche by calculating the following metrics: the sample-size corrected standard ellipse area $\left(\mathrm{SEA}_{\mathrm{C}}\right)$ for every consumer species and in every zone combination, the $\mathrm{SEA}_{\mathrm{C}}$ overlap of a given species between different depths, the Bayesian standard ellipse area $\left(\mathrm{SEA}_{\mathrm{B}}\right)$, as well as the ellipse metrics eccentricity (E) and angle (theta $-\theta$ ) for every species in the different zones. Then we assessed the potential contribution of each possible resource to the diet of the examined species. SEA $\mathrm{C}_{\mathrm{C}}$ reflects the twodimensional $\left(\delta^{13} \mathrm{C}\right.$ and $\left.\delta^{15} \mathrm{~N}\right)$ isotopic niche of a group of individuals. It is insensitive to small sample sizes $<10-$ Jackson et al., 2011; Demopoulos et al., 2017) and is a proxy of the trophic niche of that group of individuals (Jackson et al., 2011). SEA $_{B}$ provides a range of ellipse surfaces that can be valid given the input data and it was calculated from $10^{4}$ posterior iterations of $\mathrm{SEA}_{\mathrm{B}}$ (Jackson et al., 2011). Bayesian inference allows a direct probabilistic interpretation of the differences in SEA depending on the grouping level (i.e., between the individuals of the same species sampled at different depth zones). Pair-wise comparisons of SEA $\mathrm{B}$ estimate the probability that the isotopic niche of a species in one zone is larger than in another zone
(Jackson et al., 2011). Eccentricity E is a measure of the circularity of the SEA $\mathrm{C}_{\mathrm{C}}$ and therefore of the variance along the $\mathrm{x}\left({ }^{13} \mathrm{C}\right)$ and $y\left(\delta^{15} \mathrm{~N}\right)$ axes. Eccentricity $(\mathrm{E})$ values of the standard ellipse range between 0 and 1 , where $\mathrm{E}=0$ is a perfect circle, while $\mathrm{E} \sim 1$ indicates higher elongation of the standard ellipse (Reid et al., 2016). Hence, low $\mathrm{E}$ (values $\sim 0$ ) reflects similar variance on both axes and high $\mathrm{E}$ (values $\sim 1$ ) indicates that the ellipse is more elongated along one of the two axes (Reid et al., 2016). Theta $(\theta)$ is a measure of the inclination of the ellipse and is returned as a value between 0 and $\pi$ (Jackson et al., 2011). It is reported here in an angular range between -90 and $+90^{\circ}$, with positive and negative values indicating that $\delta^{13} \mathrm{C}$ and $\delta^{15} \mathrm{~N}$ are, respectively, directly or inversely proportional (Demopoulos et al., 2017). $\theta$ values close to 0 (ellipse dispersed along the $\mathrm{x}$-axis) indicate utilization of multiple resources while $\theta$ values close to (-) 90 (ellipse dispersed along the y-axis) indicate that the individuals within a site feed across different trophic positions within (a) basal carbon source(s) (Reid et al., 2016; Demopoulos et al., 2017). The combination of $\mathrm{E}$ and $\theta$ can distinguish isotopic niche areas, which have similar sizes, but the relationship between $\delta^{13} \mathrm{C}$ and $\delta^{15} \mathrm{~N}$ among locations (in this case depth zones) and/or species is different (Reid et al., 2016). SEA,$S_{C}$ SEA $_{C}$ overlap, SEA $B$ and the ellipse metrics $E$ and $\theta$ were calculated using the SIBER (Stable Isotope Bayesian Ellipses in R) package (Jackson et al., 2011).

The contribution of each potential resource to the diet of each species was calculated using the R-package SIMMR (Stable Isotope Mixing Models in R) (Parnell et al., 2013; Parnell and Inger, 2019). Bayesian isotope mixing models are based on the assumption that all dietary resources are included in the analysis (Phillips et al., 2014). Therefore, we attempted to sample as many of the known resources in the area as possible. However, we acknowledge that we probably did not collect all of them. The main advantage of this model is that it takes into account both the mean $\left(\mu_{\text {prey }}\right)$ and the standard deviation $\left(\sigma_{\text {prey }}\right)$ of the prey stable isotope ratios in order to evaluate the likelihood of the proportion of a given prey item in the diet (Moore and Semmens, 2008). We investigated the species-specific variation in resource preferences between zones by running the mixing models separately for each species and zone. This yielded information on the contribution of each resource to the diet of every species in every zone of occurrence. Resources that are not mixed along the depth 
gradient, such as macroalgae and SOM, were only included as possible resources in those zones where they were available for the consumers, i.e., the intertidal for macroalgae and the soft substrate and SPL for SOM. A trophic enrichment factor (TEF) was added to the model. Applying the relevant TEF is crucial to the design of mixing models (Phillips et al., 2014). Therefore, we ran the model multiple times, using different TEFs applied to similar consumers (Dubois and Colombo, 2014; Richoux et al., 2014; Cresson et al., 2016); based on the results of the different model runs, we chose the same TEFs as reported in Cresson et al. (2016), i.e., $1.28 \pm 0.72$ for carbon and $3.25 \pm 0.67$ for nitrogen. The choice was based on the position of the consumers within the convex polygons in the isotope space defined by the resources (Phillips et al., 2014). According to the same authors, if the consumer is positioned within the range of its resources in the $\delta^{13} \mathrm{C}-\delta^{15} \mathrm{~N}$ isospace, there is at least one solution explaining the consumer's isotopic values as a combination of the available resources. Since different species feed on different food items, the mixing models only included species-specific and zone-specific relevant food items, as deduced from literature (Table 1). Necora puber is a predator/omnivore and feeds on a combination of primary resources and invertebrate fauna. Isotope values $\left(\delta^{13} \mathrm{C}\right.$ and $\delta^{15} \mathrm{~N}$ ) for its possible invertebrate prey resources (Table 1) were obtained from Mavraki et al. (2020), who sampled these candidate prey species during the same sampling period and at the same site as reported here.

The power of mixing models to accurately describe diet composition depends both on the actual inclusion of all resources that significantly contribute to a species' diet, and on the ratio of the number of resources to the number of elements analyzed. Because of these two essentially different sources of potential bias, authors are not unanimous about the "threshold" number of resources above which model predictions become less reliable when based on $\mathrm{C}$ and $\mathrm{N}$ only. Hence, depending on what source of bias is focused on most, it has been argued that mixing model accuracy already decreases when more than three resources are included (Moore and Semmens, 2008), but also that their discriminatory power only starts to decline from six or seven resources onwards (Phillips et al., 2014). In order to avoid increasing the uncertainty of the mixing model by unnecessarily inflating the number of potential resources for a consumer (Phillips and Gregg, 2003), an a posteriori approach for combining resources was used (Table 1; Phillips et al., 2005). We used matrix plots to test the correlation between the isotopic signatures of potential resources (Parnell et al., 2010, 2013) and we combined the resources that were strongly and positively correlated for each species. Highly correlated resources generally included SPOMsurface and SPOM-bottom and were then combined and renamed to "SPOM"; the zooplanktonic organisms (copepods, crab larvae and other larvae) were often combined and referred to as "Zooplankton." Finally, algae-upper and algae-lower were combined in a "Macroalgae" resource. All data analyses were conducted in R (R Development Core Team, 2018).

\section{RESULTS}

\section{Isotopic Niche Characteristics}

Average $\delta^{13} \mathrm{C}$ values of the resources ranged between $-22.3 \pm 1.93 \%$ (SOM) or $-22.3 \pm 0.3 \%$ (SPOM-surface) and $-16.6 \%$ (Other larvae), while the average $\delta^{15} \mathrm{~N}$ values ranged between $6.0 \pm 0.8 \%$ (Algae-upper) and $11.4 \pm 0.1 \% 0$ (copepods) (Figure 2). The isotopic signatures of the consumers

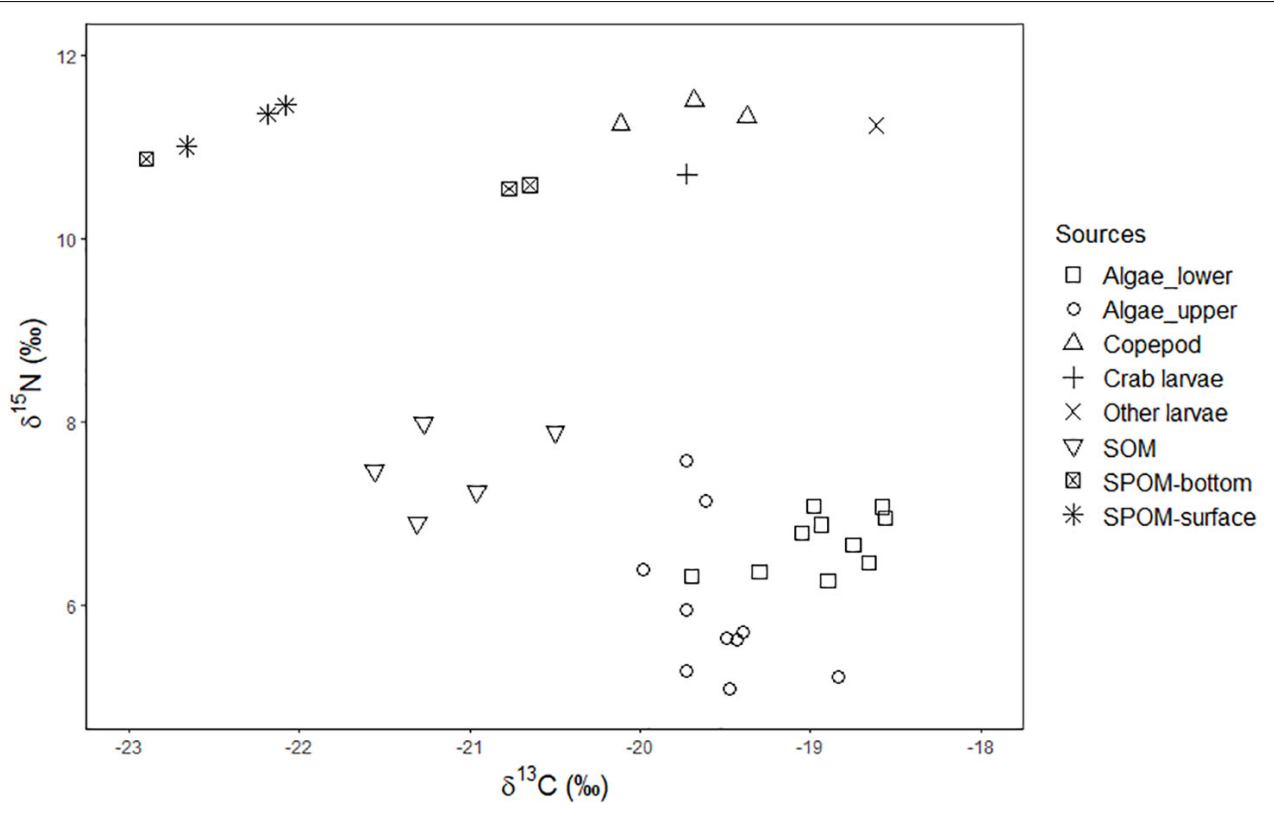

FIGURE 2 | Stable carbon $\left(\delta^{13} \mathrm{C}\right)$ and nitrogen $\left(\delta^{15} \mathrm{~N}\right)$ isotopic values $(\%)$ of the resources collected, where SPOM: suspended particulate organic matter and SOM: sediment organic matter. The different symbols represent the different resources. 

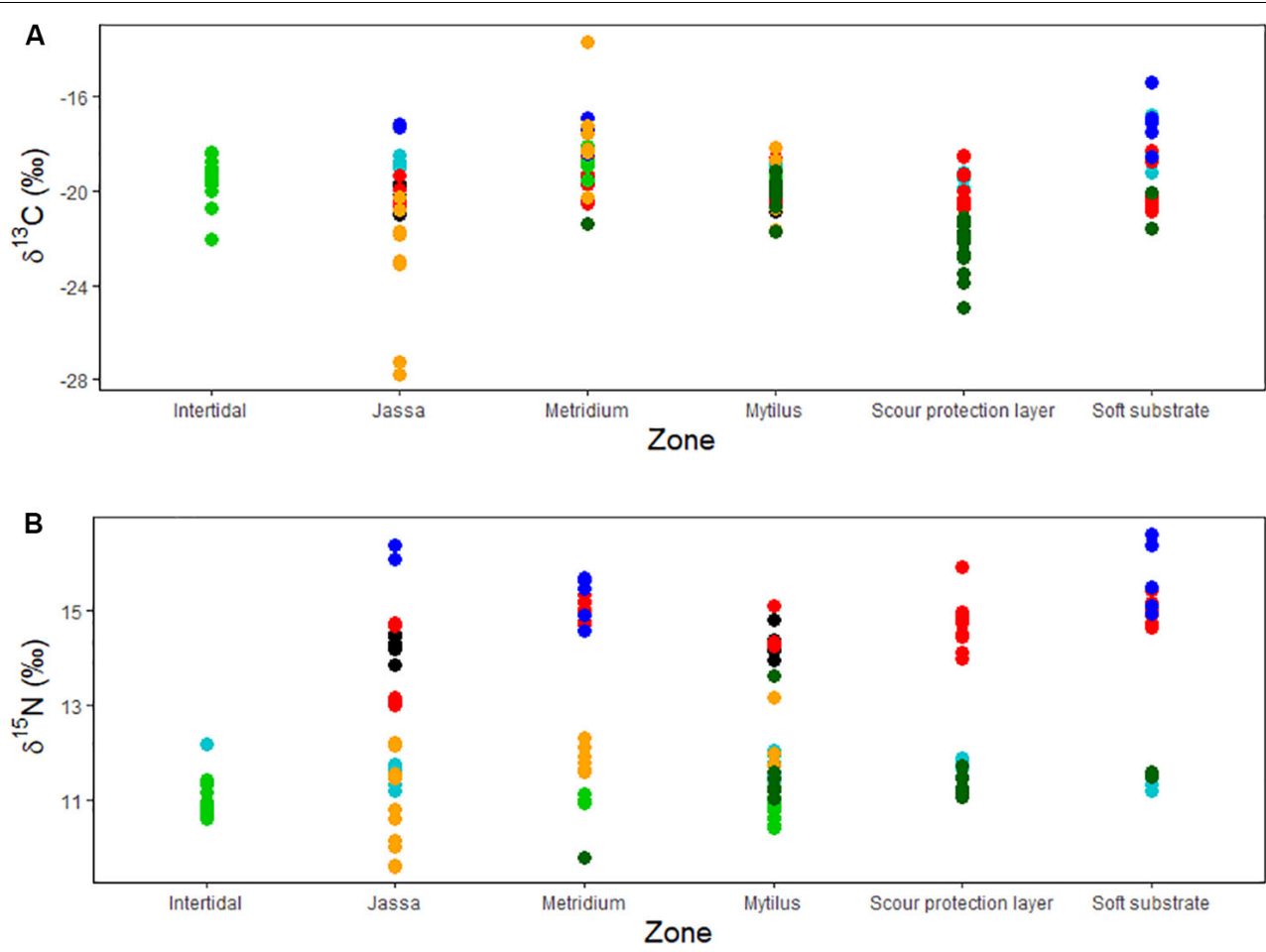

\section{Species}

- Diadumene cincta

- Jassa herdmani

- Metridium senile

- Mytilus edulis

- Necora puber

- Ophiothrix fragilis

- Pisidia longicornis

FIGURE 3 | Stable carbon $\left(\delta^{13} \mathrm{C}-\mathbf{A}\right)$ and nitrogen $\left(\delta^{15} \mathrm{~N}-\mathbf{B}\right)$ isotopic values $(\%)$ of the consumers collected in the different depth zones. The different colors represent the different species.

(Figure 3) ranged between $-23.2 \pm 2.5 \%$ (Ophiothrix fragilis in the Jassa zone) and $-17.6 \pm 2.2 \%$ (O. fragilis in the Metridium zone), while the $\delta^{15} \mathrm{~N}$ signatures ranged between $10.8 \pm 1.0 \%$ (O. fragilis in the Jassa zone) and $16.1 \pm 0.3 \%$ (Necora puber in the Jassa zone). Significant differences in the isotopic signatures among the depth zones were observed for the species Mytilus edulis [ANOVA $F_{(2,71)}=9.67, p<0.05$ ], Metridium senile [ANOVA $\left.F_{(4,79)}=14.11, p<0.05\right]$, Ophiothrix fragilis [ANOVA $F_{(2,43)}=55.95, p<0.05$ ] and Pisidia longicornis [ANOVA $\left.F_{(1,40)}=51.45, p<0.05\right]$. For the other species (Jassa herdmani, Necora puber and Diadumene cincta), no statistically significant differences among the depth-zones were found.

Intra- and inter-specific differences in the SEA $A_{C}$ were observed between/among depth zones (Supplementary Table S2). The largest $\operatorname{SEA}_{\mathrm{C}}\left(8.1 \% 0^{2}\right)$ was observed for the brittle star O. fragilis in the Jassa zone, while the smallest SEA $C\left(0.01 \% 0^{2}\right)$ was found for the hemi-sessile species J. herdmani in the SPL (Figure 4 and Supplementary Table S2). The extent of overlap of the isotopic niches differed between groups of individuals of the same species occupying different depth zones (Table 2). For P. longicornis, $M$. senile and $O$. fragilis, there was little or no overlap between their isotopic niches in the different zones, while for D. cincta and $N$. puber considerable overlap was observed between the isotopic niches of the occupied zones (Figure 4 and Table 2). Jassa herdmani and M. edulis exhibited intermediate patterns. For Jassa herdmani, the isotopic niche in the SPL did not show any overlap with any of the isotopic niches from the other zones, whereas these other zones had ellipses that showed considerable overlap.
For M. edulis, the isotopic niches in its two most important depth zones, i.e., the Mytilus and the Metridium zone, were completely separated, but the isotopic niche in the intertidal zone overlapped with that of the two other zones.

The abovementioned differences in the isotopic niches were further corroborated by the $\mathrm{SEA}_{\mathrm{B}}$, which was used to compare the isotopic niche sizes. Differences were observed at the species-specific level, as the SEA $\mathrm{B}$ of the mobile species had high probabilities (generally $>0.8$ ) of being larger than those of sessile and hemi-sessile species, with the exception of $P$. longicornis in the SPL (Figure 5, Table 3, and Supplementary Table S3). The strongest differences were observed between the hemi-sessile species J. herdmani and the mobile species $N$. puber and O. fragilis (Figure 5). Furthermore, differences were also detected within a species sampled in different zones, i.e., the probability that the $\mathrm{SEA}_{\mathrm{B}}$ of $J$. herdmani in the SPL is smaller than in any of the other zones exceeded 0.69 (Supplementary Table S3).

Generally, isotopic niches were elongated (E values close to 1) and stretched along the $\mathrm{X}$-axis (absolute $\theta$ values $<45^{\circ}-$ Supplementary Table S2). This indicates the exploitation of multiple resources by each species within every zone. However, lower $\mathrm{E}$ values were also observed for J. herdmani in the Jassa zone $(E=0.68)$, for $N$. puber in the Metridium zone $(E=0.66)$, for M. edulis in the Mytilus zone $(E=0.79)$ and for P. longicornis in the Mytilus zone $(E=0.62)$. For most of the species, there was a general tendency for $\mathrm{E}$ values to increase with increasing water depth (Figure 6 and Supplementary Table S2). The $\theta$ values were generally $<45^{\circ}$, corroborating the major trends in 

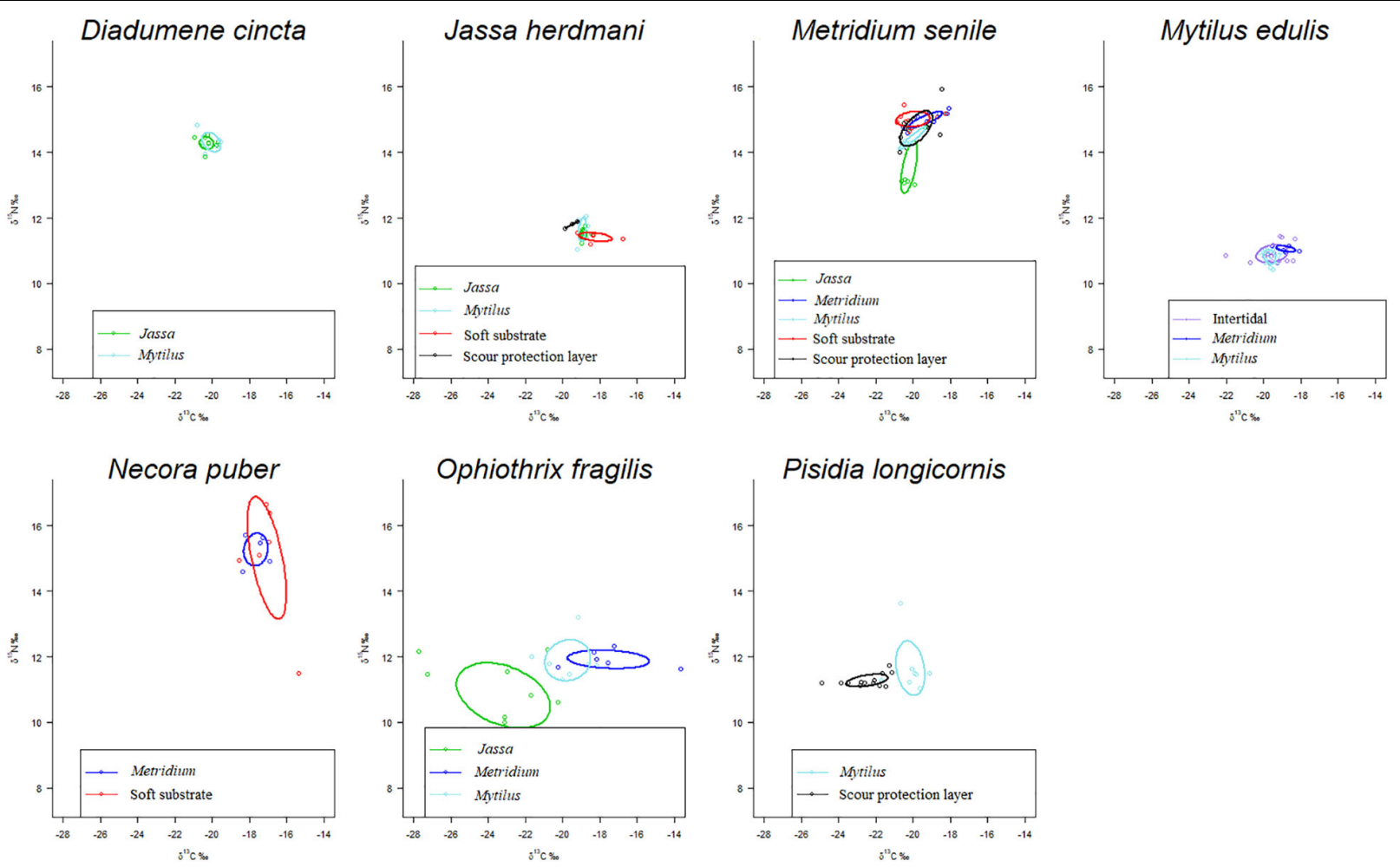

FIGURE 4 | Sample-size corrected standard ellipse areas (SEA $)$ calculated from $\delta^{13} \mathrm{C}$ and $\delta^{15} \mathrm{~N}$ values for the seven species under study collected from the different zones. The SEA $A_{C}$ include the $40 \%$ of the data. The different colors represent different zones.

E values, which also indicated utilization of a range of resources (larger spread along the $\mathrm{x}$-axis). There were nevertheless some exceptions (absolute $\theta$ values $>45^{\circ}$ ) that reflected an isotopic niche stretched along the $\mathrm{y}$-axis. Such exceptions included J. herdmani in the Mytilus zone $\left(\theta=76^{\circ}\right)$, M. senile in the Jassa zone $\left(\theta=68^{\circ}\right), N$. puber in the soft substrate $\left(\theta=-68^{\circ}\right)$ and P. longicornis in the Mytilus zone $\left(\theta=-53^{\circ}\right)$.

\section{Food Resource Contribution per Consumer}

The Bayesian stable isotope mixing models (SIMMR) revealed depth-dependent differences in resource utilization of species (Figure 7 and Supplementary Table S4). Diadumene cincta was the only species that did not show any dietary differences between the different zones it occupied, exploiting mainly SPOM in both the Mytilus and the Jassa zones (mean and standard deviation: $63.0 \pm 11.2 \%$ and $72.0 \pm 6.8 \%$ contribution to its diet, respectively). Necora puber was the only species that exploited more or less equal shares (usually $<20 \%$ ) of multiple resources at every depth zone.

The other consumers showed higher variability in their diets when sampled at different depth zones. Jassa herdmani mainly exploited zooplankton in the Jassa and Mytilus zones, while SOM was an important resource for J. herdmani from the SPL and soft substrate. The brittle star O. fragilis consumed SPOM in the Mytilus and Jassa zones (55.2 $\pm 17.4 \%$ and $59.0 \pm 20.1 \%$, respectively), but in the Metridium zone, the contribution of
SPOM to its diet was considerably lower $(31.6 \pm 17.6 \%)$. The contributions of crab and other zooplankton larvae to its diet $(25.0 \pm 19.4 \%$ and $23.9 \pm 18.3 \%$, respectively) were higher in the Metridium zone. The suspension-feeding crab P. longicornis mainly consumed SPOM $(69.0 \pm 11.7 \%)$ in the Mytilus zone but SOM $(69.0 \pm 5.4 \%)$ in the SPL. Finally, M. edulis mainly fed on macroalgal material in the intertidal $(67.2 \pm 3.9 \%)$, while SPOM was an important resource in the subtidal zones $(55.5 \pm 5.9 \%$ and $30.9 \pm 12.3 \%$ in the Mytilus and Metridium zones, respectively). However, in the Metridium zone, different resources contributed more or less equally to the diet of M. edulis.

\section{DISCUSSION}

Competition may drive species to alter their niche, thus facilitating co-existence (Svanbäck and Bolnick, 2007). The most common mechanism to avoid resource competition is niche variation, where generalist species narrow down their resource use (Van Valen, 1965; Huss et al., 2008). From this point of view - and in contrast to the alternative niche pre-emption theory (May and Arthur, 1972) - a strong competitor is not one that outcompetes other species at using the most favorable food, but one that exhibits high ("dominant") resource plasticity as a function of its competitive environment (Ashton et al., 2010).

Our results partly confirmed our hypothesis that most species that are found across multiple depth zones at an offshore wind 
TABLE 2 | Overlaps $\left(\%_{0}^{2}\right)$ of the sample-size corrected standard ellipse areas $\left(S E A_{C}\right)$ between the groups of the same species collected at different zones.

\begin{tabular}{|c|c|c|}
\hline \multicolumn{3}{|l|}{ Diadumene cincta } \\
\hline Mytilus zone & Jassa zone & 0.20 \\
\hline \multicolumn{3}{|l|}{ Jassa herdmani } \\
\hline Scour protection layer & Jassa zone & 0.00 \\
\hline Scour protection layer & Mytilus zone & 0.00 \\
\hline Scour protection layer & Soft substrate & 0.00 \\
\hline Jassa zone & Mytilus zone & 0.09 \\
\hline Jassa zone & Soft substrate & 0.07 \\
\hline Mytilus zone & Soft substrate & 0.07 \\
\hline \multicolumn{3}{|l|}{ Metridium senile } \\
\hline Scour protection layer & Jassa zone & 0.07 \\
\hline Scour protection layer & Metridium zone & 0.31 \\
\hline Scour protection layer & Mytilus zone & 0.25 \\
\hline Scour protection layer & Soft substrate & 0.43 \\
\hline Jassa zone & Metridium zone & 0.00 \\
\hline Jassa zone & Mytilus zone & 0.02 \\
\hline Jassa zone & Soft substrate & 0.00 \\
\hline Metridium zone & Mytilus zone & 0.00 \\
\hline Metridium zone & Soft substrate & 0.26 \\
\hline Mytilus zone & Soft substrate & 0.00 \\
\hline \multicolumn{3}{|l|}{ Mytilus edulis } \\
\hline Intertidal zone & Metridium zone & 0.10 \\
\hline Intertidal zone & Mytilus zone & 0.22 \\
\hline Metridium zone & Mytilus zone & 0.00 \\
\hline \multicolumn{3}{|l|}{ Necora puber } \\
\hline Metridium zone & Soft substrate & 1.08 \\
\hline \multicolumn{3}{|l|}{ Ophiothrix fragilis } \\
\hline Jassa zone & Metridium zone & 0.00 \\
\hline Jassa zone & Mytilus zone & 0.00 \\
\hline Metridium zone & Mytilus zone & 0.63 \\
\hline \multicolumn{3}{|l|}{ Pisidia longicornis } \\
\hline Scour protection layer & Mytilus zone & 0.00 \\
\hline
\end{tabular}

turbine would exhibit depth-specific resource use strategies. This was demonstrated by the significant differences of the isotopic signatures among different depth zones, by the limited overlaps of the isotopic niches of a given species between different depths, and by depth-specific differences in their diet composition. These data support the idea of a considerable trophic plasticity, which was not related to the mobility of the species, since it was observed for both sessile and mobile species. Only the anemone Diadumene cincta proved to be a resource specialist, consuming SPOM irrespective of the zone where it was sampled.

\section{Food Resources and Isotopic Niches}

The organisms occurring on offshore wind turbines have access to a wide range of food resources. These resources are generally well-mixed along the depth gradient of $\sim 27 \mathrm{~m}$ (Franco et al., 2010; Braeckman et al., 2014). From the potential resources that we sampled, zooplankton, SPOM, SOM and macroalgae were highly exploited by most of the invertebrate species (excluding Necora puber). The carbon and energy content of these resources differs, with zooplankton being the most energy-rich, followed by macroalgae, SPOM, and finally SOM (Wilson and Parkes, 1998).
The results of our study indicate that the organisms occurring in deeper zones have generally broader trophic niches than those in the upper zones. This implies that these organisms have access to a wide range of sedimentary sources, which are enriched around the base of the turbine foundations. Indeed, the biodeposition of faces and pseudofaeces by filter-feeders (mainly Mytilus edulis) growing on offshore wind turbines enriches the nearby surroundings (Coates et al., 2014), increasing both the availability, diversity and quality range of resources in the SPL and the soft substrate close to the turbines (Mavraki et al., 2020). This may well explain why organisms from deeper zones generally exhibited isotopic niches that were more stretched along the $\mathrm{x}$-axis (high $\mathrm{E}$ values and $\theta<45^{\circ}$ ), compared to their conspecifics from shallower zones (Reid et al., 2016; Tabak et al., 2016). Diadumene cincta, M. edulis and O. fragilis mainly had negative $\theta$ values indicating that an increase in their $\delta^{13} \mathrm{C}$ values was associated with a decrease in $\delta^{15} \mathrm{~N}$, while the other species mainly had positive $\theta$ values, implying that $\delta^{13} \mathrm{C}$ and $\delta^{15} \mathrm{~N}$ covaried positively (Reid et al., 2016).

\section{Trophic Plasticity of Fouling Fauna}

The resource utilization patterns shown by the mixing models at least partly confirmed the depth-dependence of feeding strategies indicated by the isotopic niche descriptors (section Food resources and Isotopic Niches). As a direct consequence of these depth-specific feeding strategies, species like M. edulis, M. senile, J. herdmani, O. fragilis, N. puber, and P. longicornis act as resource generalists when considering the entire depth range they occupy on a turbine, while having narrower diets at the scale of single depth zones. This leads to zone-specific isotopic niches (Figure 4), often with limited or no overlap (Table 2). Such switching between resource-use strategies can be an important mechanism to avoid resource competition (Bolnick et al., 2003; Lefebvre et al., 2009), and demonstrates a large degree of trophic plasticity of these species.

The diet of M. edulis in the Mytilus zone consisted mainly of SPOM (55.5 $\pm 5.9 \%)$, which is considered an energy-poor resource (Wilson and Parkes, 1998; David et al., 2006), while it largely obtained carbon from macroalgae $(67.2 \pm 3.9 \%)$ when in the intertidal (Supplementary Table S4). Macroalgae are abundantly present on offshore wind turbines in the North Sea, where they mostly consist of Porphyra spp. and Ulva spp. (Bouma and Lengkeek, 2008). While M. edulis cannot directly graze on macroalgae, it can filter fine particulate macroalgal detritus which becomes suspended due to waves and tidal action (Dubois et al., 2007). In the Metridium zone, by contrast, $70 \%$ of the diet of M. edulis consisted of various zooplankton groups (mainly crab larvae and copepods), SPOM still accounting for the remaining $30 \%$. A large dependence of $M$. edulis on zooplankton is in line with previous studies (Lehane and Davenport, 2002; Wong and Levinton, 2006; Maar et al., 2007), but could result in resource competition with M. senile, which is the dominant species in this zone and feeds mainly on zooplankton. However, we suggest that zooplankton is abundant enough to fulfill the energy demands of both species.

Still, it should be noted that M. edulis feeds on a lowerquality resource in its own zone of dominance. There are 


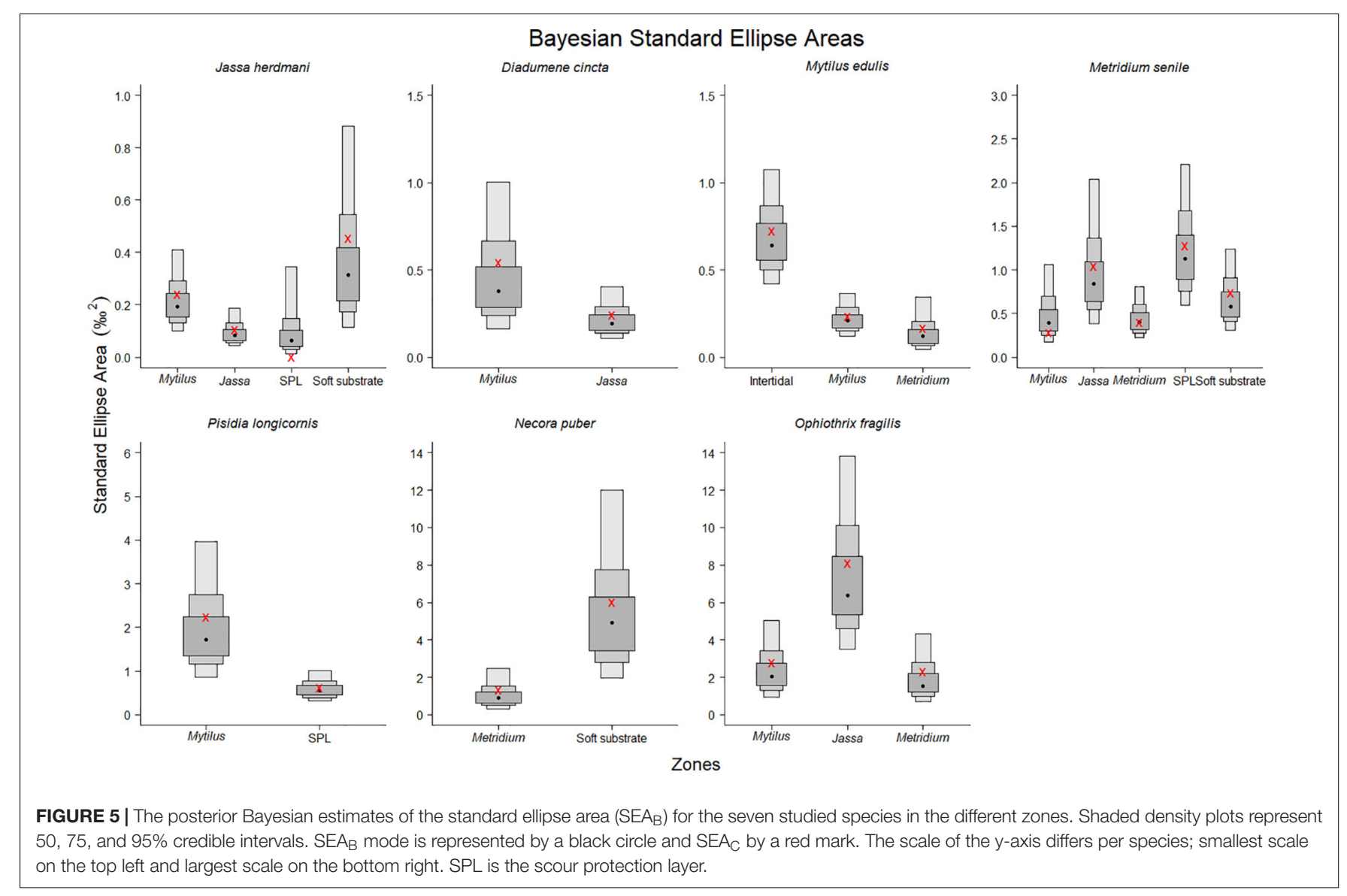

two possible explanations for this; either SPOM is much more abundant closer to the sea surface compared to the deeper areas, or there is higher intraspecific competition within the Mytilus zone than there is interspecific competition. Support for the higher availability of SPOM near the surface can be found in the diet of most species (D. cincta, M. edulis, M. senile, P. longicornis, O. fragilis), which exploited SPOM in the Mytilus and Jassa zones, while zooplankton was mainly exploited in deeper zones. Indeed, high surface concentrations of suspended particulate matter have been documented as sediment plumes by aerial photography (Vanhellemont and Ruddick, 2014) and acoustic data (Baeye and Fettweis, 2015) in the OWF areas in the BPNS. These are normally obvious shortly after strong storm events (Pleskachevsky et al., 2005), but the construction of turbines induces their production due to the changes in the hydrodynamics and sediment transport, affecting the turbidity (Baeye and Fettweis, 2015). Plumes are associated with the wakes of single turbines, and their tidal stream and direction change with the tide cycle (Vanhellemont and Ruddick, 2014). The duration of the plumes differs with the tidal cycle and seasonality (Baeye and Fettweis, 2015), but they are persistent, since they are continuously repeating with each current reversal (Vanhellemont and Ruddick, 2014). This indicates that the concentration of SPOM can often be very high near the water surface, and therefore zooplankton densities will be relatively decreased there. Thus, it is possible that the organisms exploit the resource that is ad libitum, shifting their diets synchronously toward this non-limiting resource (Lefebvre et al., 2009). Alternatively, it is possible that M. edulis shows higher intraspecific than interspecific competition in its own zone of dominance, leading to high competition between the M. edulis individuals for the limiting energy-rich resources and finally, to the exploitation of the non-limiting SPOM by the majority of them (Troost et al., 2010).

Metridium senile fed on both zooplankton $(59.3 \pm 12.9 \%)$ and SPOM $(40.7 \pm 12.9 \%)$ in its own depth zone, while in other depth zones, it mainly utilized SPOM (>56\%, Supplementary Table S4). The latter strategy may allow it to coexist with J. herdmani in the Jassa zone, where the highly abundant J. herdmani predominantly feeds on zooplankton (Supplementary Table S4). In the Mytilus zone, the feeding strategy of $M$. senile with a focus on SPOM may bring it in direct competition with $M$. edulis. There are two possible explanations for this dietary shift; either $M$. senile avoids competition with J. herdmani in the Mytilus zone, or it is energetically more favorable to feed on SPOM which is probably available in non-limiting quantities (see above), given that most of the species in the Mytilus and Jassa zones (except J. herdmani) primarily relied on SPOM.

Jassa herdmani mainly fed on zooplankton in every depth zone. In the SPL and in soft substrate, the contribution of SOM increased substantially to $30 \%$ and more 
TABLE 3 | Bayesian standard ellipse area $\left(S_{B} A_{B}\right)$ probabilities (prob) that the ellipse area of one group ( $\mathrm{g} 1$ ) is smaller than the other (g2).

\begin{tabular}{|c|c|c|}
\hline \multicolumn{3}{|l|}{ Diadumene cincta } \\
\hline g1 & g2 & prob \\
\hline Mytilus & Jassa & 0.0055 \\
\hline \multicolumn{3}{|l|}{ Jassa herdmani } \\
\hline g1 & g2 & prob \\
\hline Mytilus & Jassa & 0.32475 \\
\hline Mytilus & Scour protection layer & 0.22075 \\
\hline Mytilus & Soft substrate & 0.9555 \\
\hline Jassa & Scour protection layer & 0.3175 \\
\hline Jassa & Soft substrate & 0.98125 \\
\hline Scour protection layer & Soft substrate & 0.96875 \\
\hline \multicolumn{3}{|l|}{ Metridium senile } \\
\hline g1 & g2 & prob \\
\hline Mytilus & Jassa & 0.91075 \\
\hline Mytilus & Metridium & 0.36175 \\
\hline Mytilus & Scour protection layer & 0.7485 \\
\hline Mytilus & Soft substrate & 0.65925 \\
\hline Jassa & Metridium & 0.024 \\
\hline Jassa & Scour protection layer & 0.19825 \\
\hline Jassa & Soft substrate & 0.1305 \\
\hline Metridium & Scour protection layer & 0.88425 \\
\hline Metridium & Soft substrate & 0.81675 \\
\hline Scour protection layer & Soft substrate & 0.3785 \\
\hline \multicolumn{3}{|l|}{ Mytilus edulis } \\
\hline g1 & g2 & prob \\
\hline Intertidal & Mytilus & 0.0005 \\
\hline Intertidal & Metridium & 0.00075 \\
\hline Mytilus & Metridium & 0.1725 \\
\hline \multicolumn{3}{|l|}{ Necora puber } \\
\hline g1 & g2 & prob \\
\hline Metridium & Soft substrate & 0.99225 \\
\hline \multicolumn{3}{|l|}{ Ophiothrix fragilis } \\
\hline g1 & g2 & prob \\
\hline Mytilus & Jassa & 0.94775 \\
\hline Mytilus & Metridium & 0.3625 \\
\hline Jassa & Metridium & 0.02675 \\
\hline \multicolumn{3}{|l|}{ Pisidia longicornis } \\
\hline g1 & g2 & prop \\
\hline Mytilus & Scour protection layer & 0.00025 \\
\hline
\end{tabular}

(Supplementary Table S4), but zooplankton remained the predominant resource. However, J. herdmani is not a sediment dwelling organism and its presence there can be explained by individuals that have become dislodged from the turbine (Bouma and Lengkeek, 2012; Mavraki et al., 2020). Their isotopic signatures likely reflect in part their original position along the turbine depth gradient and in another part an opportunistic and little selective use of the most available resource(s) at or near the sediment. In general, our results suggest that J. herdmani is a strong competitor for zooplankton, as evidenced by the higher contribution of zooplankton to its diet than to that of any other consumer in every zone where J. herdmani occurred (Supplementary Table S4). Indeed, other species largely exploited zooplankton in the Metridium zone, where J. herdmani was rare.

Similarly, dietary shifts were also observed for mobile consumer species (Figure 4), suggesting that these do not dwell the turbine and its environment in search of a preferred resource. Pisidia longicornis individuals sampled from the Mytilus zone mainly fed on SPOM $(68.5 \pm 11.7 \%)$, while the diet of individuals from the SPL was dominated by SOM $(69.3 \pm 5.4 \%)$. The size of the trophic niche $\left(\mathrm{SEA}_{\mathrm{C}}\right)$ of $P$. longicornis was also considerably larger in the Mytilus zone than in the soft sediments (Figure 4 and Supplementary Table S2), which may be a strategy of minimizing competition with $M$. edulis by broadening its trophic niche while sharing a substantial part of its resources with that species.

Ophiothrix fragilis is a deposit/suspension feeder that mainly consumed SPOM in the Mytilus (55.2 $\pm 17.4 \%$ ) and Jassa $(59 \pm 20.1 \%$ ) zones, but the contribution of SPOM to its diet dropped by almost half in the Metridium zone, where O. fragilis mainly fed on crab and other larvae (up to 70\%). These feeding strategies may bring $O$. fragilis in direct competition with $M$. edulis in the Mytilus zone and with $M$. senile in the Metridium zone. At the same time, it would limit competition between $O$. fragilis and J. herdmani, a strategy that is further enforced by a pronounced increase in the size of its trophic niche $\left(\mathrm{SEA}_{\mathrm{B}}\right.$, Figure 5) in the Jassa zone. It is nevertheless important to note that niche expansion at the population level may not only follow from a decrease in interspecific competition, but also from an increase in intraspecific competition, because the latter may drive individuals to minimize niche overlap with conspecifics by narrowing their resource use (Svanbäck and Bolnick, 2007; Violle et al., 2012). As such, the considerably larger isotopic niche of $M$. edulis in the intertidal zone, for instance, may also reflect strong intraspecific competition. Because isotopic niches are calculated at a "population level" (i.e., for a group of individuals) rather than at an individual level, our data can only demonstrate the degree of variation within a population, but not the niche width of individual consumers, and hence cannot prove the ecological mechanism causing the observed variation.

In contrast to $O$. fragilis, Necora puber, exhibited no or only small differences in trophic niche between the Metridium zone and the soft substrate (Figure 4). In the Metridium zone, $N$. puber was partly feeding on the small crab Pilumnus hirtellus $(20.6 \pm 17.9 \%)$, while in the soft substrate, no specific dietary preferences were observed. This indicates that $N$. puber does not narrow its resource range and/or shifts to different food sources depending on the depth zone where it occurs, and exhibits very little trophic plasticity.

Finally, D. cincta was the only trophic specialist observed in our study, and hence, the only species that did not show any trophic plasticity. Diadumene cincta mainly consumed SPOM in both the Mytilus $(62.5 \pm 11.2 \%)$ and the Jassa $(71.9 \pm 6.8 \%)$ zones (Figure 7 and Supplementary Table S4). The specialist diet of this species suggests that it cannot avoid competition with other, more dominant species. Because of their shared reliance on SPOM, trophic competition with M. edulis in the Mytilus zone is likely to occur, but in turn, limited competition is to be expected with $J$. herdmani, since the latter species predominantly preys on zooplankton. 


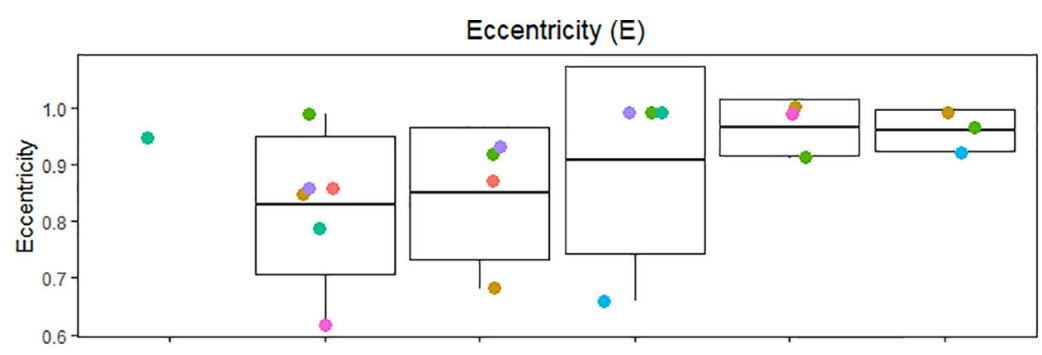

\section{Species}

- Diadumene cincta

- Jassa herdmani

- Metridium senile

Theta $(\theta)$

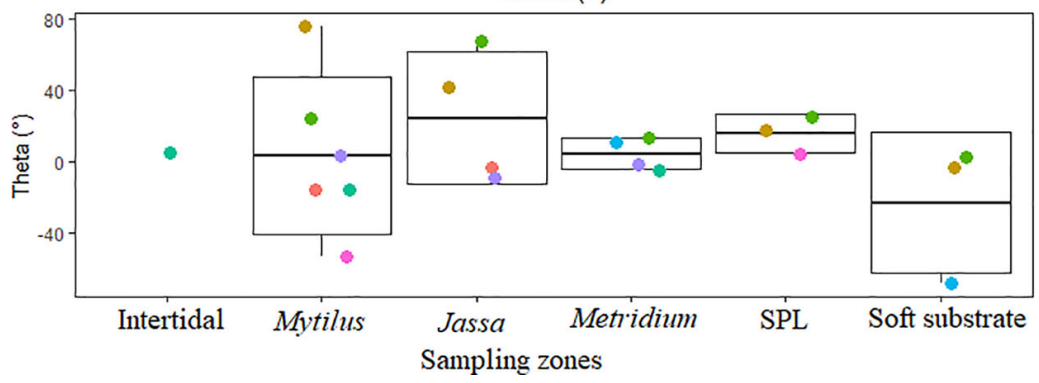

- Mytilus edulis

- Necora puber

- Ophiothrix fragilis

- Pisidia longicornis

Sampling zones

FIGURE 6 | Eccentricity ( $\mathrm{E}$ - upper graph) and theta $\left(^{\circ}\right)(\theta$ - lower graph) values of every species in the different zones (Intertidal, Mytilus, Jassa, Metridium, Scour Protection Layer - SPL and soft substrate). Each boxplot represents the median (middle horizontal line) and the lower and upper quartile (the lower and upper end of the boxplots, respectively) of eccentricity and theta in the different zones, while the whiskers represent the extreme highest and lowest observations. Intertidal was the only zone without enough replicates to generate a boxplot.
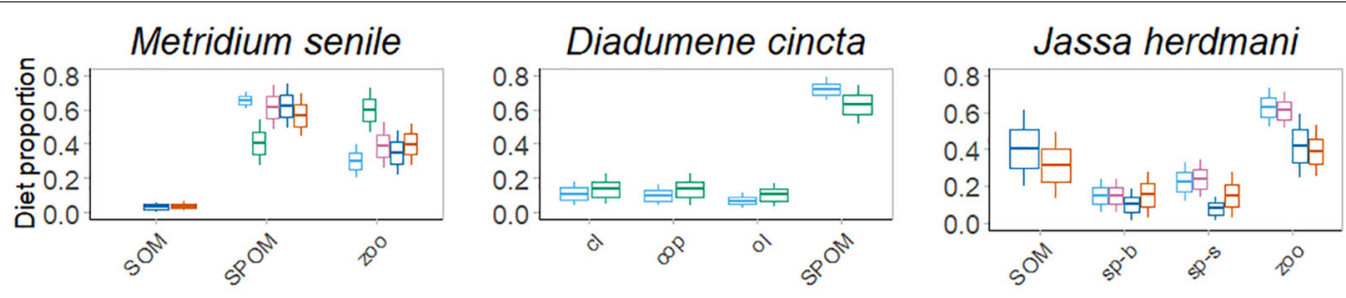
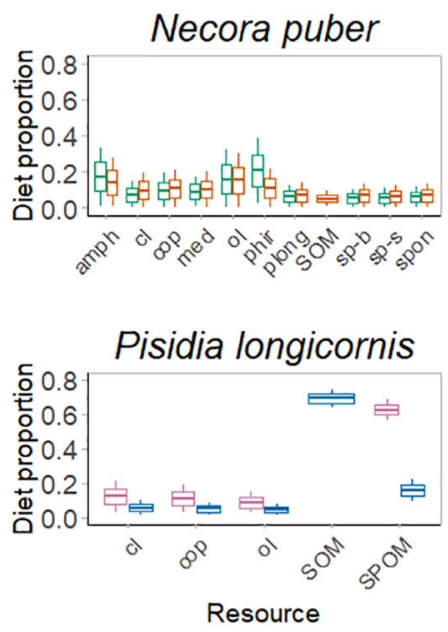

\section{Mytilus edulis}

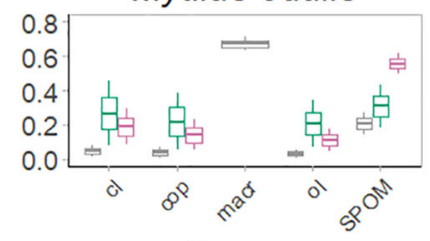

Resource

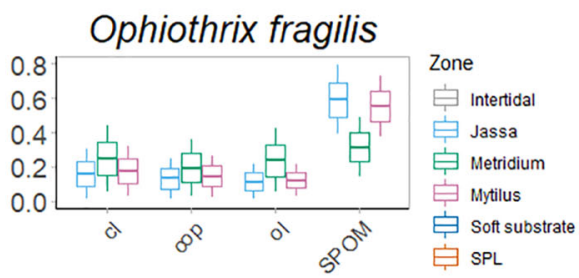

Resource 
In general, the seven consumer species investigated here covered three different resource strategies: resource specialization (D. cincta), intermediate dietary shifts with depth (N. puber) and trophic plasticity (all five other consumers). When species are exposed to anthropogenic stress - as may for instance be increasingly the case as a consequence of climate change - flexible and differential resource strategies may provide them with (extra) spatial refuges and thus buffer their populations against costs imposed by the impacts of stressors on their environment (MacDonald et al., 2019). Our results extend the well-recognized importance of trophic plasticity as a major driver of vertical zonation in, for instance, shallow coral-reef (Palardy et al., 2008; Friedlander et al., 2010; Fox et al., 2019) and deep-sea communities (Carney, 2005) to hard-substrate fauna in shallow coastal waters, where zonation patterns are commonly explained in relation to predation, competition for space and food (the latter mostly among suspension feeders), and tolerance to environmental conditions toward the limits of a species' depth range (Kaiser et al., 2011).

\section{Methodological Considerations}

The $\delta^{13} \mathrm{C}$ values of SPOM and SOM were highly similar, which is in line with a previous study conducted in the area (Franco et al., 2008). This could be explained by the composition of SOM, which partly consists of deposited SPOM particles and partly of the fecal pellets derived from the biodeposition of the fouling organisms (Coates et al., 2014). The $\delta^{15} \mathrm{~N}$ values of SPOM were almost identical to the $\delta^{15} \mathrm{~N}$ values of zooplankton. Such similarities in the $\delta^{15} \mathrm{~N}$ values between SPOM and zooplankton have been previously reported in summer and autumn in the Mediterranean Sea (Banaru et al., 2014). Therefore, SPOM in our samples could contain a range of different particles, each with somewhat different isotopic signatures, that influenced the overall SPOM isotopic values but also the estimates of the contributions of SPOM and SOM to the diet of consumers.

In addition, we probably did not collect all the available potential resources (i.e., diatoms, bacteria, detritus, etc.). A significant contribution of bacteria to the diet of suspension feeding organisms, such as the blue mussel Mytilus edulis (Kreeger and Newell, 1996) and the brittle star Ophiothrix fragilis, might explain the unexpectedly low $\delta^{15} \mathrm{~N}$ values measured for suspension feeding organisms (Cresson et al., 2016). Bacteria represent an important proportion of the organic carbon content in marine food webs (Richoux and Froneman, 2008) and are considered a potential resource both for bivalves (Maar et al., 2007; Mueller et al., 2013; Cresson et al., 2016; Demopoulos et al., 2017) and for O. fragilis (Migne et al., 2012).

Finally, for most of our consumers, the number of resources included in the mixing models was $\leq 5$ and thus within an acceptable range (see Phillips et al., 2014), with the exception of N. puber, where we incorporated 11 resources (Figure 7). While this large number of resources may have reduced the power of the diet reconstruction of $N$. puber, available literature underlines that this species' diet consists of multiple resources and did not provide clear clues about resources that we could have omitted or pooled (see Table 1). Moreover, the model did not suggest an a posteriori combination of the resources, implying that it can provide a valid solution, by preserving the covariation structure among the source proportions (Phillips et al., 2014).

\section{CONCLUSION}

Our study provides insight into the feeding strategies and dietary composition of invertebrate species associated with offshore wind turbine foundations. A considerable degree of trophic plasticity was observed for both sessile and mobile species, indicating that they exploit at least partly different resources in different depth zones. The isotopic niches of most species were highly horizontally elongated in deeper zones, which suggests that organisms consumed resources with distinct $\delta^{13} \mathrm{C}$ values that are accumulated in the SPL and the surrounding soft sediments, but also that there was considerable intraspecific variation in diet. Our results suggested that Diadumene cincta was the only trophic specialist, since it predominantly fed on SPOM in both zones where it occurred. All the other species showed zone-specific dietary shifts, which may well represent a way to avoid trophic competition with the dominant species of each zone and/or a strategy to feed on energetically more favorable food sources. Jassa herdmani appeared to be a dominant competitor for zooplankton, since its occurrence in any depth zone coincided with a very limited or no contribution of zooplankton to the diets of the other species in that zone. Trophic plasticity is likely a key mechanism allowing the co-existence of invertebrate organisms within and across depth zones at an offshore wind turbine, in line with other aquatic habitats and communities where trophic plasticity is known to contribute to depth zonation patterns, such as shallow coral reef communities (Palardy et al., 2008; Friedlander et al., 2010; Fox et al., 2019) and deep-sea communities (Carney, 2005).

\section{DATA AVAILABILITY STATEMENT}

The datasets (stable isotope data, dates of the sampling campaigns and further details) for this study can be found in the Marine Data Archive of Flanders Marine Institute (https://mda.vliz.be/archive.php).

\section{AUTHOR CONTRIBUTIONS}

ID, TM, SD, and JV conceived this study. NM collected the data, analyzed the data with support of JV and TM and wrote the manuscript with valuable inputs and edits by all the other co-authors.

\section{FUNDING}

This work was part of the FaCE-It project - Functional Biodiversity in a Changing Sedimentary Environment: Implications for biogeochemistry and food webs in a managerial 
setting - funded by the Belgian Science Policy Office (BELSPO, contract BR/154/A1/FaCE-It).

\section{ACKNOWLEDGMENTS}

We would like to acknowledge the crew of R.V. Simon Stevin for help with sampling at sea; Francis Kerckhof and Jan Ranson for help with the identification of the organisms and the collection of the intertidal samples. The research leading to results presented in this publication was supported by EMBRC Belgium as we

\section{REFERENCES}

Allen, J. R. (1998). Suspension feeding in the brittle-star Ophiothrix fragilis: efficiency of particle retention and implications for the use of encounter-rate models. Mar. Biol. 132, 383-390.

Andrade, C., Ríos, C., Gerdes, D., and Brey, T. (2016). Trophic structure of shallowwater benthic communities in the sub-Antarctic Strait of Magellan. Polar Biol. 39, 2281-2297. doi: 10.1007/s00300-016-1895-0

Araújo, M. S., Bolnick, D. I., and Layman, C. A. (2011). The ecological causes of individual specialisation. Ecol. Lett. 14, 948-958. doi: 10.1111/j.1461-0248.2011. 01662.x

Ashton, I. W., Miller, A. E., Bowman, W. D., and Suding, K. N. (2010). Niche complementarity due to plasticity in resource use: plant partitioning of chemical N forms. Ecology 91, 3252-3260. doi: 10.1890/09-1849.1

Baeye, M., and Fettweis, M. (2015). In situ observations of suspended particulate matter plumes at an offshore wind farm, southern North Sea. Geo Mar. Lett. 35, 247-255. doi: 10.1007/s00367-015-0404-8

Bayne, B. L., Hawkins, A. S., Navarro, E., and Iglesias, I. P. (1989). Effects of seston concentration on feeding, digestion and growth in the mussel Mytilus edulis. Mar. Ecol. Prog. Ser. 55, 47-54.

Bearhop, S., Adams, C. E., Waldron, S., Fuller, R. A., and Macleod, H. (2004). Determining trophic niche width: a novel approach using stable isotope analysis. J. Anim. Ecol. 73, 1007-1012. doi: 10.1111/j.0021-8790.2004.00861.x

Beermann, J., and Boos, K. (2015). Flexible microhabitat partitioning between hemi-sessile congeners. Mar. Ecol. Prog. Ser. 520, 143-151.

Bode, A., Alvarez-Ossorio, M. T., and Varela, M. (2006). Phytoplankton and macrophyte contributions to littoral food webs in the Galician upwelling estimated from stable isotopes. Mar. Ecol. Prog. Ser. 318, 89-102.

Bolnick, D. I., Priyanga, A., Araújo, M. S., Bürger, R., Levine, J. M., Novak, M., et al. (2011). Why intraspecific trait variation matters in community ecology. Trends Ecol. Evol. 26, 183-192. doi: 10.1016/j.tree.2011.01.009

Bolnick, D. I., Svanbäck, R., Fordyce, J., Yang, L., Davis, J., Hulsey, C., et al. (2003). The ecology of individuals: incidence and implications of individual specialization. Am. Nat. 161, 1-28.

Bordeyne, F., Davoult, D., Migné, A., Bertaud du Chazaud, E., Leroux, C., and Riera, P. (2017). Trophic structure of two intertidal Fucus spp. communities along a vertical gradient: similarity and seasonal stability evidenced with $\delta^{13} \mathrm{C}$ and $\delta^{15}$ N. J. Sea Res. 120, 50-59. doi: 10.1016/j.seares.2016.12.004

Bouma, S., and Lengkeek, W. (2008). Benthic communities on hard substrates within the first Dutch offshore wind farm (OWEZ). Rep. Bur. Waardenbg. Noordzeewind 2008:84.

Bouma, S., and Lengkeek, W. (2012). Benthic Communities on Hard Substrates of the Offshore Wind Farm Egmond an Zee OWEZ- Including Results of Samples Collected in Scour Holes. Final Report 2012. IJmuiden: Noordzeewind, 80.

Brabant, R., and Degraer, S. (2010). "A brief introduction to offshore wind farms in the Belgian part of the North Sea, in," in Offshore Wind Farms in the Belgian Part of the North Sea: State of the Art after Two Years of Environmental Monitoring, eds S. Degraer, R. Brabant, and B. Rumes (Brussels: Royal Belgian Institute of Natural Sciences), 13-16.

Brabant, R., and Jacques, T. G. (2010). "Chapter 2. introduction: offshore wind energy development in the Belgian part of the North Sea \& anticipated impacts," in Offshore Wind Farms in the Belgian Part of the North Sea: Early Environmental Impact Assessment and Spatio-temporal Variability, eds S. are indebted to the scientific divers Patrick Hendricks, Daniel Marsham, Alain Norro, Francesca Pasotti, Bob Rumes, Marc van Espen and David Vuylsteke for their valuable contribution to the collection of the samples.

\section{SUPPLEMENTARY MATERIAL}

The Supplementary Material for this article can be found online at: https://www.frontiersin.org/articles/10.3389/fmars. 2020.00379/full\#supplementary-material

Degraer, R. Brabant, and B. Rumes (Brussels: Royal Belgian Institute of Natural Sciences), 9-18.

Braeckman, U., Foshtomi, M. Y., Van Gansbeke, D., Meysman, F., Soetaert, K., Vincx, M., et al. (2014). Variable importance of macrofaunal functional biodiversity for biogeochemical cycling in temperate coastal sediments. Ecosystems 17, 720-737. doi: 10.1007/s10021-014-9755-7

Buss, L. W., and Jackson, J. B. C. (1981). Planktonic food availability and suspension-feeder abundance: evidence of in situ depletion. J. Exp. Mar. Biol. Ecol. 49, 151-161.

Banaru, D., Carlotti, F., Barani, A., Grégori, G., Neffati, N., and HarmelinVivien, M. (2014). Seasonal variation of stable isotope ratios of size-fractionated zooplankton in the Bay of Marseille (NW Mediterranean Sea). J. Plankton Res. 36, 145-156. doi: 10.1093/plankt/fbt083

Carney, R. S. (2005). "Zonation of deep biota on continental margins," in Oceanography and Marine Biology, eds R. N. Gibson, R. J. A. Atkinson, and J. D. M. Gordon (Boca Raton, FL: CRC Press), 221-288.

Coates, D. A., Deschutter, Y., Vincx, M., and Vanaverbeke, J. (2014). Enrichment and shifts in macrobenthic assemblages in an offshore wind farm area in the Belgian part of the North Sea. Mar. Environ. Res. 95, 1-12. doi: 10.1016/j. marenvres.2013.12.008

Côté, J., Himmelman, J. H., and Claereboudt, M. R. (1994). Separating effects of limited food and space on growth of the giant scallop Placopecten magellanicus in suspended culture. Mar. Ecol. Prog. Ser. 106, 85-91.

Cresson, P., Ruitton, S., and Harmelin-Vivien, M. (2016). Feeding strategies of cooccurring suspension feeders in an oligotrophic environment. Food Webs 6, 19-28. doi: 10.1016/j.fooweb.2015.12.002

David, V., Sautour, B., Galois, R., and Chardy, P. (2006). The paradox high zooplankton biomass - low vegetal particulate organic matter in high turbidity zones: what way for energy transfer? J. Exp. Mar. Bio. Ecol. 333, 202-218. doi: 10.1016/j.jembe.2005.12.045

De Mesel, I., Kerckhof, F., Norro, A., Rumes, B., and Degraer, S. (2015). Succession and seasonal dynamics of the epifauna community on offshore wind farm foundations and their role as stepping stones for nonindigenous species. Hydrobiologia 756, 37-50. doi: 10.1007/s10750-0142157-1

De Mesel, I., Kerckhof, F., Rumes, B., Norro, A., Houziaux, J. H., and Degraer, S. (2013). "Fouling community on the foundations of wind turbines and the surrounding scour protection," in Environmental Impacts of Offshore Wind Farms in the Belgian Part of the North Sea: Learning from the Past to Optimise Future Monitoring Programmes, eds S. Degraer, R. Brabant, and B. Rumes (Brussels: Royal Belgian Institute of Natural Sciences, Operational Directorate Natural Environment, Marine Ecology and Management Section), 122-138.

Demopoulos, A. W. J., McClain-Counts, J., Ross, S. W., Brooke, S., and Mienis, F. (2017). Food-web dynamics and isotopic niches in deep-sea communities residing in a submarine canyon and on the adjacent open slopes. Mar. Ecol. Prog. Ser. 578, 19-33. doi: 10.3354/meps 12231

Dubois, S., Orvain, F., Marin-Léal, J. C., Ropert, M., and Lefebvre, S. (2007). Small-scale spatial variability of food partitioning between cultivated oysters and associated suspension-feeding species, as revealed by stable isotopes. Mar. Ecol. Prog. Ser. 336, 151-160.

Dubois, S. F., and Colombo, F. (2014). How picky can you be? Temporal variations in trophic niches of co-occurring suspension-feeding species. Food Webs 1, 1-9. doi: 10.1016/j.fooweb.2014.07.001 
Fox, M. D., Elliott Smith, E. A., Smith, J. E., and Newsome, S. D. (2019). Trophic plasticity in a common reef-building coral: insights from $\delta^{13} \mathrm{C}$ analysis of essential amino acids. Funct. Ecol. 33, 2203-2214. doi: 10.1111/1365-2435. 13441

Franco, M., de, A., Vanaverbeke, J., Van Oevelen, D., Soetaert, K., Costa, M. J., et al. (2010). Respiration partitioning in contrasting subtidal sediments: seasonality and response to a spring phytoplankton deposition. Mar. Ecol. 31, 276-290. doi: 10.1111/j.1439-0485.2009.00319.x

Franco, M. A., Soetaert, K., Van Oevelen, D., Van Gansbeke, D., Costa, M. J., Vincx, M., et al. (2008). Density, vertical distribution and trophic responses of metazoan meiobenthos to phytoplankton deposition in contrasting sediment types. Mar. Ecol. Prog. Ser. 358, 51-62. doi: 10.3354/meps07361

Freire, J., and Gonzalez-Gurriaran, E. (1995). Feeding ecology of the velvet swimming crab Necora puber in mussel raft areas of the Ria de Arousa (Galicia, NW Spain). Mar. Ecol. Prog. Ser. 119, 139-154. doi: 10.3354/meps119139

Friedlander, A. M., Sandin, S. A., DeMartini, E. E., and Sala, E. (2010). Spatial patterns of the structure of reef fish assemblages at a pristine atoll in the central Pacific. Mar. Ecol. Prog. Ser. 410, 219-231. doi: 10.3354/meps08634

Gili, J. M., and Coma, R. (1998). Benthic suspension feeders: their paramount role in littoral marine food webs. Trends Ecol. Evol. 13, 316-321. doi: 10.1016/S01695347(98)01365-2

Goering, J., Alexander, V., and Haubenstock, N. (1990). Seasonal variability of stable carbon and nitrogen isotope ratios of organisms in a North Pacific bay. Estuar. Coast. Shelf Sci. 30, 239-260.

Gutt, A. (2006). Coexistence of macro-zoobenthic species on the Antarctic shelf: an attempt to link ecological theory and results. Deep Res. II 53, 1009-1028. doi: 10.1016/j.dsr2.2006.02.012

Hazlett, B. A. (1988). "Behavioural plasticity as an adaptation to a variable environment," in Behavioural Adaptations to the Intertidal Life, eds G. Chelazzi and M. Vannini (Boston, MA: Springer), 317-332.

Huss, M., Byström, P., and Persson, L. (2008). Resource heterogeneity, diet shifts and intra-cohort competition: effects on size divergence in YOY fish. Oecologia 158, 249-257. doi: 10.1007/s00442-008-1140-9

Jackson, A. L., Inger, R., Parnell, A. C., and Bearhop, S. (2011). Comparing isotopic niche widths among and within communities: SIBER - stable isotope Bayesian ellipses in R. J. Anim. Ecol. 80, 595-602. doi: 10.1111/j.1365-2656.2011.01806.x

Jacob, U., Mintenbeck, K., Brey, T., Knust, R., and Beyer, K. (2005). Stable isotope food web studies: a case for standardized sample treatment. Mar. Ecol. Prog. Ser. 287, 251-253. doi: 10.1179/joc.2011.23.1.32

Kaiser, M. J., Attrill, M. J., Jennings, S., Thomas, D. N., and Barnes, D. K. (2011). Marine Ecology: Processes, Systems, and Impacts. Oxford: Oxford University Press.

Kerckhof, F., Rumes, B., Jacques, T., Degraer, S., and Norro, A. (2010). Early development of the subtidal marine biofouling on a concrete offshore windmill foundation on the Thornton Bank (southern North Sea): first monitoring results. Underw. Technol. 29, 137-149. doi: 10.3723/ut.29.137

Kreeger, D. A., and Newell, R. I. E. (1996). Ingestion and assimilation of carbon from cellulolytic bacteria and heterotrophic flagellates by the mussels Geukensia demissa and Mytilus edulis (Bivalvia, Mollusca). Aquat. Microb. Ecol. 11, 205214.

Krone, R., Gutow, L., Joschko, T. J., and Schröder, A. (2013). Epifauna dynamics at an offshore foundation - implications of future wind power farming in the North Sea. Mar. Environ. Res. 85, 1-12. doi: 10.1016/j.marenvres.2012. 12.004

Lancelot, C., Spitz, Y., Gypens, N., Ruddick, K., Becquevort, S., Rousseau, V., et al. (2005). Modelling diatom and Phaeocystis blooms and nutrient cycles in the Southern Bight of the North Sea: the MIRO model. Mar. Ecol. Prog. Ser. 289, 63-78. doi: 10.3354/meps289063

Layman, C. A., Quattrochi, J. P., Peyer, C. M., and Allgeier, J. E. (2007). Niche width collapse in a resilient top predator following ecosystem fragmentation. Ecol. Lett. 10, 937-944. doi: 10.1111/j.1461-0248.2007.01087.x

Lefebvre, S., Leal, J. C. M., Dubois, S., Orvain, F., Blin, J.-L., Bataille, M.-P., et al. (2009). Seasonal dynamics of trophic relationships among co-occurring suspension- feeders in two shellfish culture dominated ecosystems. Estuar. Coast. Shelf Sci. 82, 415-425. doi: 10.1016/j.ecss.2009.02.002

Lehane, C., and Davenport, J. (2002). Ingestion of mesozooplankton by three species of bivalve; Mytilus edulis, Cerastoderma edule and Aequipecten opercularis. J. Mar. Biol. Ass. Unit. King. 82, 615-619.
Lindeboom, H. J., Kouwenhoven, H. J., Bergman, M. J. N., Bouma, S., Brasseur, S., Daan, R., et al. (2011). Short-term ecological effects of an offshore wind farm in the Dutch coastal zone; A compilation. Environ. Res. Lett. 1341, 35101-35113. doi: 10.1088/1748-9326/6/3/035101

Lorrain, A., Savoye, N., Chauvaud, L., Paulet, Y. M., and Naulet, N. (2003). Decarbonation and preservation method for the analysis of organic $\mathrm{C}$ and $\mathrm{N}$ contents and stable isotope ratios of low-carbonated suspended particulate material. Anal. Chim. Acta 491, 125-133. doi: 10.1016/S0003-2670(03)00815-8

Maar, M., Nielsen, T. G., Bolding, K., Burchard, H., and Visser, A. W. (2007). Grazing effects of blue mussel Mytilus edulis on the pelagic food web under different turbulence conditions. Mar. Ecol. Prog. Ser. 339, 199-213. doi: 10.3354/ meps339199

MacDonald, C., Bridge, T. C. L., McMahon, K. W., and Jones, G. P. (2019). Alternative functional strategies and altered carbon pathways facilitate broad depth ranges in coral-obligate reef fishes. Funct. Ecol. 33, 1962-1972. doi: 10. 1111/1365-2435.13400

MacNeil, C., Dick, J. T. A., and Elwood, R. W. (1997). The trophic ecology of freshwater Gammarus spp. (Crustacea: Amphipoda): problems and perspectives concerning the functional feeding group concept. Biol. Rev. 72, 349-364.

Mavraki, N., Degraer, S., Moens, T., and Vanaverbeke, J. (2020). Functional differences in trophic structure of offshore wind farm communities: a stable isotope study. Mar. Environ. Res. 157:104868. doi: 10.1016/j.marenvres.2019. 104868

May, R. M., and Arthur, R. H. M. (1972). Niche overlap as a function of environmental variability. Proc. Natl. Acad. Sci. U.S.A. 69, 1109-1113.

Migne, A., Riera, P., Janquin, M. A., Leroux, C., Muths, D., and Davoult, D. (2012). Carbon and nitrogen assimilation by the suspension-feeding brittle-star Ophiothrix fragilis from two localities in the English Channel. Life Environ. 62, 47-53.

Moncreiff, C. A., and Sullivan, M. J. (2001). Trophic importance of epiphytic algae in subtropical seagrass beds: evidence from multiple stable isotope analysis. Mar. Ecol. Prog. Ser. 215, 93-106.

Moore, J. W., and Semmens, B. X. (2008). Incorporating uncertainty and prior information into stable isotope mixing models. Ecol. Lett. 11, 470-480. doi: 10.1111/j.1461-0248.2008.01163.x

Mueller, C. E., Lundälv, T., Middelburg, J. J., and van Oevelen, D. (2013). The symbiosis between Lophelia pertusa and Eunice norvegica stimulates coral calcification and worm assimilation. PLoS One 8:e58660. doi: 10.1371/journal. pone. 0058660

Nelson, M. L., and Craig, S. F. (2011). Role of the sea anemone Metridium senile in structuring a developing subtidal fouling community. Mar. Ecol. Prog. Ser. 421, 139-149.

Newsome, S. D., del Rio, C. M., Bearhop, S., and Phillips, D. L. (2007). A niche for isotopic ecology. Front. Ecol. Environ. 5, 429-436. doi: 10.1890/060150.01

Östman, C., Kultima, J. R., and Roat, C. (2010). Tentacle cnidae of the sea anemone Metridium senile (Linnaeus, 1761) (Cnidaria: Anthozoa). Sci. Mar. 74, 511-521.

Páez-Rosas, D., Villegas-Amtmann, S., and Costa, D. (2017). Intraspecific variation in feeding strategies of Galapagos sea lions: a case of trophic specialization. PLoS One 12:e0185165. doi: 10.1371/journal.pone.0185165

Palardy, J. E., Rodrigues, L. J., and Grottoli, A. G. (2008). The importance of zooplankton to the daily metabolic carbon requirements of healthy and bleached corals at two depths. J. Exp. Mar. Bio. Ecol. 367, 180-188. doi: 10.1016/ j.jembe.2008.09.015

Parnell, A. C., and Inger, R. (2019). Stable Isotope Mixing Models in R with SIMMR: A Stable Isotope Mixing Model. Version 0.4.1. Available online at: https://cran.rproject.org/web/packages/simmr/ (accessed July 3, 2019).

Parnell, A. C., Inger, R., Bearhop, S., and Jackson, A. L. (2010). Source partitioning using stable isotopes: coping with too much variation. PLoS One 5:e9672. doi: 10.1371/journal.pone.0009672

Parnell, A. C., Phillips, D. L., Bearhop, S., Semmens, B. X., Ward, E. J., Moore, J. W., et al. (2013). Bayesian stable isotope mixing models. Environmetrics 24, 387-399. doi: 10.1002/env.2221

Peire, K., Nonneman, H., and Bosschem, E. (2009). Gravity based foundations for the Thornton Bank offshore wind farm. Terra Aqua 115, 19-29.

Phillips, D. L., and Gregg, J. W. (2003). Source partitioning using stable isotopes: coping with too many sources. Oecologia 136, 261-269. doi: 10.1007/s00442003-1218-3 
Phillips, D. L., Inger, R., Bearhop, S., Jackson, A. L., Moore, J. W., Parnell, A. C., et al. (2014). Best practices for use of stable isotope mixing models in food-web studies. Can. J. Zool. 92, 823-835. doi: 10.1139/cjz-2014-0127

Phillips, D. L., Newsome, S. D., and Gregg, J. W. (2005). Combining sources in stable isotope mixing models: alternative methods. Oecologia 144, 520-527. doi: 10.1007/s00442-004-1816-8

Pinnegar, J. K., and Polunin, N. V. C. (1999). Differential fractionation of $\delta^{13} \mathrm{C}$ and $\delta^{15} \mathrm{~N}$ among fish tissues: implications for the study of trophic interactions. Funct. Ecol. 13, 225-231. doi: 10.1046/j.1365-2435.1999.00301.x

Pleskachevsky, A., Gayer, G., Horstmann, J., and Rosenthal, W. (2005). Synergy of satellite remote sensing and numerical modeling for monitoring of suspended particulate matter. Ocean Dyn. 55, 2-9. doi: 10.1007/s10236-004-0101-z

R Development Core Team (2018). A Language and Environment for Statistical Computing. Vienna: R Foundation for Statistical Computing.

Reid, W. D. K., Sweeting, C. J., Wigham, B. D., McGill, R. A. R., and Polunin, N. V. C. (2016). Isotopic niche variability in macroconsumers of the East Scotia Ridge (Southern Ocean) hydrothermal vents: what more can we learn from an ellipse? Mar. Ecol. Prog. Ser. 542, 13-24. doi: 10.3354/meps11571

Renaud, P. E., Løkken, T., Jørgensen, L. L., Berge, J., and Johnson, B. J. (2015). Macroalgal detritus and food-web subsidies along an Arctic fjord depthgradient. Front. Mar. Sci. 2:31. doi: 10.3389/fmars.2015.00031

Richoux, N. B., and Froneman, P. W. (2008). Trophic ecology of dominant zooplankton and macrofauna in a temperate, oligotrophic South African estuary: a fatty acid approach. Mar. Ecol. Prog. Ser. 357, 121-137. doi: 10.3354/ meps07323

Richoux, N. B., and Ndhlovu, R. T. (2015). Temporal variability in the isotopic niches of rocky shore grazers and suspension-feeders. Mar. Ecol. 36, 1045-1059. doi: 10.1111/maec.12200

Richoux, N. B., Vermeulen, I., and Froneman, P. W. (2014). Fatty acid profiles reveal temporal and spatial differentiation in diets within and among syntopic rocky shore suspension-feeders. Mar. Ecol. Prog. Ser. 495, 143-160. doi: 10. 3354/meps10581

Riera, P. (2009). Trophic plasticity in similar habitats: an example which severely limits generalization among ecosystems. Mar. Biodivers. Rec. 2, 1-4. doi: 10 . 1017/s1755267209000529

Ross, S. T. (1986). Resource partitioning in fish assemblages - a review of field studies. Copeia 2, 352-388.

Sampedro, M. P., Freire, F. J., and González-Gurriaran, E. (1997). Fecundity and reproductive output of Pisidia longicornis (Decapoda, Anomura) in the Ria de Arousa (Galicia, NW Spain). Crustaceana 70, 95-110.

Sebens, K. P. (1981). The allometry of feeding, energetics, and body size in three sea anemone species. Biol. Bull. 161, 152-171.

Slavik, K., Lemmen, C., Zhang, W., Kerimoglu, O., Klingbeil, K., and Wirtz, K. W. (2018). The large-scale impact of offshore wind farm structures on pelagic primary productivity in the southern North Sea. Hydrobiologia 845, 35-53. doi: 10.1007/s10750-018-3653-5

Smaldon, G. (1972). Population structure and breeding biology of Pisidia longicornis and Porcellana platycheles. Mar. Biol. 17, 171-179.

Smyntek, P. M., Teece, M. A., Schulz, K. L., and Thackeray, S. J. (2007). A standard protocol for stable isotope analysis of zooplankton in aquatic food web research using mass balance correction models. Limnol. Oceanogr. 52, 2135-2146. doi: 10.4319/lo.2007.52.5.2135

Soma, K., van den Burg, S. W. K., Selnes, T., and van der Heide, C. M. (2019). Assessing social innovation across offshore sectors in the Dutch North Sea. Ocean Coast. Manag. 167, 42-51. doi: 10.1016/j.ocecoaman.2018.10.003

Svanbäck, R., and Bolnick, D. I. (2007). Intraspecific competition drives increased resource use diversity within a natural population. Proc. R. Soc. B Biol. Sci. 274, 839-844.

Svensson, J. R., and Marshall, D. J. (2015). Limiting resources in sessile systems: food enhances diversity and growth of suspension feeders despite available space. Ecology 96, 819-827. doi: 10.1890/14-0665.1
Tabak, M. A., Anderson, O. R. J., Robb, G., Poncet, S., Passfield, K., Martinez, M. G., et al. (2016). Comparative isotopic natural history of two native passerines (Troglodytes cobbi and Cinclodes antarcticus) and the invasive rats (Rattus norvegicus) that extirpate them. Austral Ecol. 41, 622-632. doi: 10.1111/aec. 12351

Troost, T. A., Wijsman, J. W. M., Saraiva, S., and Freitas, V. (2010). Modelling shellfish growth with dynamic energy budget models: an application for cockles and mussels in the Oosterschelde (southwest Netherlands). Philos. Trans. R. Soc. B Biol. Sci. 365, 3567-3577. doi: 10.1098/rstb.2010.0074

Vafeiadou, A.-M., Adão, H., De Troch, M., and Moens, T. (2013). Sample acidification effects on carbon and nitrogen stable isotope ratios of macrofauna from a Zostera noltii bed. Mar. Freshw. Res. 64, 741-745. doi: 10.1071/MF12169

Van den Eynde, D., Brabant, R., Fettweis, M., Francken, F., Melotte, J., Sas, M., et al. (2010). "Monitoring of hydrodynamic and morphological changes at the C-Power and the Belwind offshore wind farm sites - a synthesis," in Offshore Wind Farms in the Belgian Part of the North Sea: Early Environmental Impact Assessment and Spatiotemporal Variability, eds S. Degraer, R. Brabant, and B. Rumes (Brussels: Royal Belgian Institute of Natural Sciences), 19-36.

van der Stap, T., Coolen, J. W. P., and Lindeboom, H. J. (2016). Marine fouling assemblages on offshore gas platforms in the southern North Sea: effects of depth and distance from shore on biodiversity. PLoS One 11:e0146324. doi: 10.1371/journal.pone.0146324

Van Valen, L. (1965). Morphological variation and width of ecological niche. Am. Nat. 99, 377-390.

Vanhellemont, Q., and Ruddick, K. (2014). Turbid wakes associated with offshore wind turbines observed with Landsat 8. Remote Sens. Environ. 145, 105-115. doi: 10.1016/j.rse.2014.01.009

Violle, C., Enquist, B. J., Mcgill, B. J., Jiang, L., Albert, C. H., Hulshof, C., et al. (2012). The return of the variance: intraspecific variability in community ecology. Trends Ecol. Evol. 27, 244-252. doi: 10.1016/j.tree.2011.11.014

Warner, G. F. (1971). On the ecology of a dense bed of the brittle-star Ophiothrix fragilis. J. Mar. Biol. Assoc. 51, 267-282. doi: 10.1017/S0025315400031775

Wilhelmsson, D., and Malm, T. (2008). Fouling assemblages on offshore wind power plants and adjacent substrata. Estuar. Coast. Shelf Sci. 79, 459-466. doi: 10.1016/j.ecss.2008.04.020

Wilson, J. G., and Parkes, A. (1998). Network analysis of the energy flow through the Dublin Bay ecosystem. Biol. Environ. Proc. R. Irish Acad. 98, $179-190$.

WindEurope (2018). Offshore Wind in Europe-Key Trends and Statistics 2017. Available online at: https://windeurope.org/wp-content/uploads/files/aboutwind/statistics/WindEurope-Annual-Offshore-Statistics-2017.pdf (accessed January 10, 2020).

Wong, W. H., and Levinton, J. S. (2006). The trophic linkage between zooplankton and benthic suspension feeders: direct evidence from analyses of bivalve faecal pellets. Mar. Biol. 148, 799-805. doi: 10.1007/s00227-005-0096-0

Zhang, Y., DeLaney, K., Hui, L., Wang, J., Sturm, R. M., and Li, L. (2018). A multifaceted mass spectrometric method to probe feeding related neuropeptide changes in Callinectes sapidus and Carcinus maenas. J. Am. Soc. Mass Spectrom. 29, 948-960. doi: 10.1007/s13361-017-1888-4

Conflict of Interest: The authors declare that the research was conducted in the absence of any commercial or financial relationships that could be construed as a potential conflict of interest.

Copyright (c) 2020 Mavraki, De Mesel, Degraer, Moens and Vanaverbeke. This is an open-access article distributed under the terms of the Creative Commons Attribution License (CC BY). The use, distribution or reproduction in other forums is permitted, provided the original author(s) and the copyright owner(s) are credited and that the original publication in this journal is cited, in accordance with accepted academic practice. No use, distribution or reproduction is permitted which does not comply with these terms. 